Federal Reserve Bank of Dallas

Globalization and Monetary Policy Institute

Working Paper No. 25

http://www.dallasfed.org/assets/documents/institute/wpapers/2009/0025.pdf

\title{
Do China and Oil Exporters Influence Major Currency Configurations?*
}

\author{
Marcel Fratzscher \\ European Central Bank \\ Arnaud Mehl \\ European Central Bank
}

January 2009

\begin{abstract}
This paper analyses the impact of the shift away from a US dollar focus of systemically important emerging market economies (EMEs) on configurations between the US dollar, the euro and the yen. Given the difficulty that fixed or managed US dollar exchange rate regimes remain pervasive and reserve compositions mostly kept secret, the identification strategy of the paper is to analyse the market impact on major currency pairs of official statements made by EME policy-makers about their exchange rate regime and reserve composition. Developing a novel database for 18 EMEs, we find that such statements not only have a statistically but also an economically significant impact on the euro, and to a lesser extent the yen against the US dollar. The findings suggest that communication hinting at a weakening of EMEs' US dollar focus contributed substantially to the appreciation of the euro against the US dollar in recent years. Interestingly, EME policy-makers appear to have become more cautious in their communication more recently. Overall, the results underscore the growing systemic importance of EMEs for global exchange rate configurations.
\end{abstract}

JEL codes: E58, F30, F31, F36, G15

\footnotetext{
* Marcel Fratzscher, European Central Bank, Kaiserstrasse 29, D-60311 Frankfurt am Main, Germany. +49-69-1344-6871. marcel.fratzscher@ecb.int. Arnaud Mehl, European Central Bank, Kaiserstrasse 29, D-60311 Frankfurt am Main, Germany. arnaud.mehl@ecb.int. We wish to thank Barbara Meller for excellent research assistance, Claus Brand, Philippine Cour-Thimann, Michael Ehrmann and Jean-Pierre Vidal for discussion as well as participants in two ECB seminars for comments. The views in this paper are those of the authors and do not necessarily reflect the views of the European Central Bank, the Federal Reserve Bank of Dallas or the Federal Reserve System.
} 


\section{Introduction}

How would a change to the exchange rate regimes of China and oil-exporting countries affect exchange rate configurations across major currencies? And similarly, how does a diversification and rebalancing of global foreign exchange reserves alter these currency configurations? These are arguably two of today's most pertinent issues influencing exchange rate dynamics, in particular of the US dollar, the euro and the yen. Understanding the answers to these questions is also crucial for gauging the direction in which the international monetary system may evolve, and the role that the US dollar and the euro will play in the future.

The fundamental difficulty for understanding the potential implications of this regime shift is that many of the systemically important emerging market economies (EMEs) still maintain a fixed or at least highly inflexible exchange rate regime vis-àvis the US dollar. Hence it is difficult to predict what major currency configurations will be once EMEs have moved to more flexible and open currency regimes. Moreover, the composition and diversification decisions of reserves by most EMEs are mostly closely held secret.

This paper exploits the market reaction to official communications by key policy-makers of systemically important EMEs in order to overcome these difficulties. These are statements that provide information to financial markets about policy-makers' views and preferences about exchange rates and reserves. While this empirical strategy surely only captures a limited share of the true information that becomes available to financial markets about EME currency and reserve choices, the strength of this approach is that it allows for a clean identification of factors that are specific to these EMEs, and the measurement of how they affect global exchange rate configurations. In short, the estimation of the impact of such communications at daily frequency enables us to obtain an idea of how global exchange rate configurations are affected by an overall shift of EMEs away from pursuing an exchange rate strategy with a sole focus on the US dollar.

The paper develops a novel database of statements by key policy-makers of 18 EMEs - including China, Russia, countries of the Gulf Cooperation Council (GCC: Saudi Arabia, Oman, UAE, Kuwait, Bahrain and Qatar) as well as other smaller EMEs - comprising statements on these countries' exchange rate regimes and reserve composition. In fact, there have been frequent statements in recent years by policymakers from most of these EMEs in that they are considering or pursuing an objective of moving away from a pure US dollar peg, or that they are contemplating reserve diversification out of US dollar assets. These intensified in 2003/04 as the US dollar started declining, and they peaked in 2006. Interestingly, policy-makers in China and in oil-exporting countries appear to have become much more cautious in their communication about moving away from the US dollar in 2007, possibly partly reflecting the increased capital flows into these economies due to changed expectations about currency and reserve policies. Overall, our novel database includes 199 statements on the exchange rate regime and 68 statements on foreign reserves by policy-makers in the 18 EMEs. 
Our primary interest is on how such communication affects G3 exchange rates, i.e. the reaction of the euro and the yen vis-à-vis the US dollar. The motivation for analysing this issue is both academic - as it helps shed light on what drives major exchange rates - and of relevance from a policy perspective - as the impact of exchange rate regime choices by China and oil exporting countries continues to dominate the policy debate on global currencies.

Our hypothesis is that if market participants consider such statements as credible and expect them to have an impact on major currencies, then we would expect that these statements have a depreciating effect on the US dollar against the euro and the yen. This prior follows the following logic. EME statements indicating a reserve diversification out of US dollars or the desirability of an appreciation of the domestic currency against the US dollar should both weaken the US dollar against other major currencies, and primarily through a portfolio balance channel as it may indicate ongoing or planned diversification out of US dollar assets. This channel has indeed been shown to have played some role in the past for FX interventions by central banks (see e.g. Branson, 1977; Dominguez and Frankel, 1993). But the effect of statements by EME authorities may also occur through a coordination channel, as formulated by Sarno and Taylor (2001), in which they may trigger and help coordinate expectations among market participants. Statements interpreted as suggesting a weakening by EMEs of their exchange rate policy's strong US dollar focus might, in turn, be interpreted as a signal that relative demand for global currencies is fundamentally changing, along with the future course of the international monetary system's nature.

We test this hypothesis using daily exchange rate returns of the US dollareuro, US dollar-yen and the nominal effective exchange rates of the euro, US dollar and yen in the period 2000-07. We attempt to control for other factors that may influence the estimations, in particular statements on exchange rates by G3 policymakers (US, euro area and Japan) as well as a broad set of macroeconomic news.

The main finding of the paper is that statements on exchange rates and reserves by EME policy-makers exert a statistically significant and economically meaningful impact on the euro and on the yen vis-à-vis the US dollar. Overall, it is the euro that is affected the strongest. On average, an EME statement pointing at the possibility of loosening the US dollar peg or diversifying reserves leads to an appreciation of $0.25 \%$ of the euro, and $0.15 \%$ of the yen against the US dollar. In turn, the US dollar nominal effective exchange rate depreciates by an average $0.11 \%$ when such statements occur. What seems striking is that the average effect of a statement by Chinese or GCC officials on the euro or yen against the US dollar is comparable in size to that of euro area and Japanese officials. Of course it needs to be stressed that the latter policy-makers generally communicate much more frequently on exchange rates than the former. But, overall, the result underlines that financial markets pay very close attention to statements by these EMEs, and that this reflects not only expectations about the sustainability of EMEs' currency regimes, but has a marked impact on the US dollar against the yen and in particular against the euro. 
It is of course difficult to gauge to what extent the magnitude of these estimates is economically relevant. Calculating the cumulated effect of EME statements by year shows that statements by EME officials led to an appreciation of the euro against the US dollar by as much as 7 percentage points in 2006. This indeed seems very substantial. Nevertheless, there is strong time variation in the effect of EME communication on major currencies. Few EME policy-makers talked openly about reforming exchange rate regimes or diversifying reserves before 2003, so that such communication had a relatively small overall relevance for the US dollar-euro exchange rate before 2003. Interestingly, the effect of EMEs on global exchange rate configurations also seems to have declined markedly in 2007. This might reflect the much more cautious communication of EMEs, possibly due to the increased pressure on their currency pegs from capital inflows and expectations about currency reform.

We conduct various extensions and modifications to check the robustness of the findings. Overall, the estimates are quite similar across China, Russia and GCC countries. Nevertheless, it is interesting to note that, on a cumulated basis, statements by GCC officials seem to have had a somewhat larger effect on the US dollar-euro than those by Chinese or Russian authorities. The findings are also robust to alternative classifications of the statements and their underlying intentions. Moreover, we control for various macroeconomics news from the United States and the euro area, as well as statements on exchange rates by G3 authorities. In all cases, the benchmark results are robust to these extensions.

As to the final part of the empirical analysis, we try to gauge the channels through which EME statements affect major currencies. One hypothesis that is implicit in the analysis above is that statements by EME authorities either trigger or confirm market expectations about the likelihood of a change to the exchange rate regime or to reserve composition. We find some evidence that suggests that this expectations channel is indeed important as the effect of a given statement is larger when also market expectations about a future change in the domestic currency regime, as proxied from the spread between non-deliverable forward and spot rates, increase.

The findings of the paper have a number of policy implications. First, they point out clearly that important EMEs, such as China, Russia and the GCC economies, have a systematic and sizeable impact on global exchange rate configurations. In particular given the magnitude of the reserves held by these countries, any shift in market expectations that one or several of these countries could loosen their close US dollar peg or diversify reserves affects also the major currency pairs, and in particular the euro. The results obviously do not contain any implications about what an optimal exchange rate regime choice is for these economies. But the findings suggest that policy-makers in these economies are increasingly becoming aware of the impact of their statements on global financial markets. This underlines that communication can be an important and effective policy tool that needs to be used with caution and with a clear idea of what it aims to achieve.

The paper is related to various strands in the literature. It fits most closely into the rapidly growing literature on the role of communication in managing market expectations, not just in the area of monetary policy, but also of exchange rates 
(Blinder et al., 2008). While there is ample evidence that actual FX interventions by monetary authorities influence currency values, there is also a growing area of the literature that shows that communication can be an effective tool in guiding foreign exchange markets (Beine et al. 2006; Fratzscher 2008a; Jansen and De Haan 2005, 2007; Dominguez and Panthaki 2007; Siklos and Bohl forthcoming). In fact there is evidence that communication may to some extent and under some conditions be a substitute to actual interventions in that it affects markets quite independently of the latter (Fratzscher 2008c), and also that credible communication overall enhances the effectiveness of actual interventions (Egert 2007).

The critical question is how communication can be successful in managing expectations and thus influence exchange rates. The seminal work by Sarno and Taylor (2001) stresses the functioning of a coordination channel, in which communication may not only provide new information to markets, but in which it coordinates market beliefs and moves market participants to act in a coordinated way. There is indeed evidence that such a channel is at work for FX communication in the context of major economies (Taylor 2004, Reitz and Taylor 2006, Fratzscher 2008b).

The paper is organised as follows. Section 2 discusses in detail the construction of our database on communication by EME authorities, both on FX regimes and on reserve diversification. Section 3 then gives the benchmark results and provides a number of extensions and robustness checks. Section 4 summarises the findings and concludes with a discussion of policy implications.

\section{Data and methodology}

We aim to obtain a list of public statements about the domestic exchange rate regime and reserve diversification by relevant policy-makers in 18 emerging market economies (China, 6 other emerging Asian economies ${ }^{1}, 6$ Gulf Cooperation Council economies $^{2}$ and Russia), which include also four more "other" EMEs, namely: Iraq, Iran, North Korea and Venezuela, which all have switched, or signalled their intention to do so, part of their international transactions (e.g. oil sales) or foreign reserves in euros. Our aim is to collect a list of public statements about (i) the role of the US dollar in their exchange rate regime and (ii) the composition of their foreign reserve assets that is as comprehensive as possible. Moreover, as a control group we collect statements about exchange rates by the three main currency economies, the US, the euro area and Japan.

To that end, we first identify the relevant policy-makers to include. As regards emerging market economies, we collect statements by central bank Governors in a systematic fashion, given that central banks in these economies are responsible for exchange rate policy and interventions in foreign exchange markets. When available, however, we also collect statements by Ministers of Finance and central bank ViceGovernors, although these tend to be less frequent. For China, we also have

\footnotetext{
${ }^{1}$ These include Hong-Kong, India, Malaysia, Taiwan, Singapore and South Korea.

${ }^{2}$ Bahrain, Kuwait, Oman, Qatar, Saudi Arabia and the United Arab Emirates.
} 
statements by the President of the People's Republic, the Premier and representatives of the State Administration of Foreign Exchange who have occasionally - albeit relatively rarely - expressed public views on the renminbi and/or on the composition of China's reserves. A list of those policy-makers broken down by nationality and institution is provided in Appendix I.

Turning to our control group, i.e. G3 authorities, primarily statements of the Treasury Secretary and of the Deputy Treasury Secretary are included for the United States, given that exchange rate policy lies in the realm of the US Treasury Department. $^{3}$ For the euro area, the European Union Treaty specifies a close coordination between the ECB and the Eurogroup, which both share the responsibility for official exchange rate communication. However, the ECB alone is in charge of actual foreign exchange interventions, with its overarching aim remaining the maintenance of price stability. Statements are therefore extracted for the members of the ECB Governing Council. Japan's exchange rate policy officially lies in the realm of the Ministry of Finance, although members of the Bank of Japan's Policy Board have tended to make regular statements on the yen. Hence we collect statements by both the Minister of Finance and the Governor of the Bank of Japan.

Public statements generally stem from three sources: speeches, interviews and public testimonies. In order to ensure that these public statements were also available to market participants in financial markets, one of the most commonly used wire services, Reuters News, was chosen to extract all news releases for the period 1 January 2000 to 31 December 2007, partly building on the database for the US, euro area and Japan in Fratzscher (2008c). These releases were obtained through Factiva. Reuters News has the advantage of being one of the most comprehensive wire services, reporting on and disseminating all major news in a timely fashion, usually within a short timeframe after a public announcement. It is also among those providers which receive greatest attention among traders and investors. This allows using daily data to analyse the impact of statements on exchange rates, taking exchange rate quotes at 18.00 EST, i.e. closing prices of the New York markets. ${ }^{4}$

In selecting the statements, the search criteria for public statements on the role of the US dollar in the exchange rate regime of emerging market economies were:

(a) the name or the title of the policy-maker,

(b) the word "exchange rate" or the name of the domestic currency and

\footnotetext{
${ }^{3}$ Extending the analysis to other officials, such as the Under Secretaries of the Treasury and of the Federal Reserve does not add many observations. Federal Reserve officials have made remarkably few public statements about the US dollar.

${ }^{4}$ Arguably an alternative might be to use intraday data together with the time stamps corresponding to the statements of our database. However, using intraday data is not a feasible option for improving our identification scheme because the reports of Reuters News are the articles summarising a particular statement by a policy-maker. These articles may come as soon as 20 minutes after a particular statement, or they become available several hours later in the day. Hence we cannot measure the highfrequency market response of a statement because no data is available for the initial "snaps" (i.e. realtime reporting of headlines containing at most a few words, which may occur within seconds after a statement).
} 
(c) the words "stable" or "stability" or "flexible" or "flexibility" or "dollar" or "peg".

Likewise, the search criteria for statements on the composition of foreign exchange reserves were:

(a) the name or the title of the policy-maker,

(b) the word "reserves" and

(c) the words "composition" or "diversification" or "portfolio" or "rebalancing" or "dollar".

Last, the search criteria used for the United States, the euro area and Japan were:

(a) the name or the title of the policy-maker and

(b) the word "exchange rate" or the name of the domestic currency.

Clearly, a crucial issue is how to classify the statements in terms of both content and meaning. For emerging markets, statements $S_{t}$ are categorised as either advocating that the reference to the US dollar in the exchange rate regime will be relaxed in order to let the domestic currency appreciate, or to let the domestic currency depreciate or that the exchange rate regime will be maintained.
$S_{t}^{e}=\left\{\begin{array}{l}=+1 \\ =0 \\ =-1\end{array}\right.$
US dollar reference is relaxed to appreciate
US dollar reference is maintained
US dollar reference is relaxed to depreciate

Appendix II contains examples of statements for each of those categories.

We expect that relaxing the US dollar reference to appreciate also contributes to an appreciation of the euro or the yen vis-à-vis the US dollar through the 'portfolio balance channel' (see e.g. Branson, 1977; Dominguez and Frankel, 1993; Greenspan, 2004). This relaxation would indeed imply that emerging market economies reduce their purchases of US dollar-denominated securities and, in turn, decrease demand for US dollars. Ultimately, this would contribute to a depreciation of the US dollar vis-àvis other currencies, including the euro and the yen. A coordination channel might also be at play (Sarno and Taylor, 2001), in which market participants might interpret statements by emerging economies suggesting a weakening of their exchange rate policy's strong US dollar focus as a signal that relative demand for global currencies is fundamentally changing, along with the future course of the international monetary system's nature, which thus help coordinate investor expectations.

Moreover, emerging market statements referring to the composition of foreign exchange reserves are classified as either suggesting diversification away from the US 
dollar, diversification into the US dollar or that the composition of reserves is maintained:

$$
S_{t}^{r e s}= \begin{cases}=+1 & \begin{array}{l}
\text { Diversification out of the US dollar } \\
=0
\end{array} \\
=-1 & \text { Reserve composition is maintained } \\
\text { Diversification into the US dollar }\end{cases}
$$

Appendix II contains examples of statements for each of those categories.

In the same vein, given that a large - if not dominant - share of emerging market reserves are denominated in US dollars (see e.g. ECB, 2008), we expect statements that signal intentions to diversify across currencies and/or instruments to contribute to an appreciation of the euro or the yen vis-à-vis the US dollar.

For the United States, the euro area and Japan, statements $I O_{t}$ are categorised as either advocating a stronger domestic currency ("strengthen"), a weaker domestic currency ("weaken"), or as being "neutral" in the following way:

$$
I O_{t}^{G 3}= \begin{cases}=+1 & \text { Intention to "strengthen" the domestic currency } \\ =0 & \text { "Neutral" statement } \\ =-1 & \text { Intention to "weaken" the domestic currency }\end{cases}
$$

The classification is a judgmental one and clearly in some cases difficult to make. Three points should be noted. First, the classification is done in a mechanical way, i.e. all statements are classified based on their language content and not based on their effect and importance for asset prices. Second, the only statements that are not classified and left out from the dataset are those that occurred on days of monetary policy meetings of the respective central banks or in monetary policy testimonies to the respective parliaments. It was also checked whether exchange rate statements take place during release days of relevant macroeconomic data. It is important to control for such events because the news content of monetary policy statement or data releases may have a dominant effect on those days. Third, the advantage in using newswire services is that interpretation of the statements is provided by professionals who are aware of nuances and experienced in interpreting them. In this respect, small changes to standard language may often occur intentionally to "convey a message" and have a large effect on financial markets. To account for this, we also use a dummy variable which equals 1 when a statement deviates from the predominant policy mantra and 0 otherwise.

Several additional caveats should be borne in mind, however. A first caveat is that newswire reports may not reflect the true intention of policy-makers. Moreover, some public statements may not be covered, or may to some extent contain Reuters' interpretation. Hence the list of statements may not constitute a complete list of 
official communications but only a list of statements as reported by Reuters. The objective of our paper is to analyse the reaction of market participants to policymakers' communication. It therefore seems sensible to focus only on those statement that actually become available to market participants and, again, Reuters News is among those providers that receive greatest attention among traders and investors. Last, other important statements, such as those by the G7, are not included as they generally cannot be attributed to a single country's policy-makers alone and do not refer to an individual currency (see Fratzscher 2008b for an empirical analysis of the market impact of such statements).

Tables $1.1-1.2$

Table 1.1 provides a summary of the around 200 statements by emerging market authorities we found with regard to the use of the US dollar as an anchor currency over January 2000-December 2007. The bulk of these statements (about $75 \%$ ) are from Chinese authorities ${ }^{5} ; 19 \%$ are from Gulf Cooperation Council authorities ${ }^{6}$ and $6 \%$ from Russian authorities. ${ }^{7}$ In terms of meaning and content, about two-thirds of the statements repeat a mantra that the exchange rate regime will remain unchanged and are classified as neutral. A quarter of the statements are classified as conveying a message that the reference to the US dollar in the exchange rate regime will be relaxed in order to let the domestic currency appreciate (e.g. when China switched from a strict US dollar peg to a regime allowing for more exchange rate flexibility). A few statements are classified as conveying a message that the reference to the US dollar might be relaxed to let the domestic currency depreciate (e.g. when uncertainties mounted in the wake of the Asian crisis as to whether the Chinese renminbi might be devalued).

Statements on the composition of foreign reserve assets by emerging market authorities are fewer (about 70) than those on the exchange rate regime and are summarised in Table 1.2. Less than one-fifth are from China (also in contrast with statements on the exchange rate regime), with the Governor of the People's Bank of China and representatives from the State Administration of Foreign Exchange being the main authors. More than one-third of the statements are from other emerging Asian economies (notably South Korea) and another third by Gulf Cooperation Council authorities. The remaining statements are from Russian authorities. In terms of meaning and content, the largest share (two-thirds) of the statements is classified as conveying a message that diversification across currencies and/or instruments is sought. One-fifth of the statements that repeat a mantra that the composition of foreign reserve assets will remain unchanged are classified as neutral. A few statements are classified as indicating that diversification into US dollars is sought.

Figures $1-2$

\footnotetext{
${ }^{5}$ More than one-half of these statements are from the President of the People's Bank of China.

${ }^{6}$ More than one-half of these statements are from the Governor of the Central Bank of the United Arab Emirates.

${ }^{7}$ These statements are exclusively from the Chairman or the First Deputy Chairman of the Central Bank of the Russian Federation.
} 
To further give an intuition of the data, Figures 1.1 and 1.2 plot over time the statements by emerging market officials relating to the exchange rate regime together with the USD/EUR. Statements by Chinese authorities are broadly spread over 20002007, but they were markedly more frequent in the aftermath of the Asian crisis, when the debate about a possible devaluation of the renminbi mounted and after 2004/5 with the relaxation of the US dollar peg and the adoption of a currency basket. Statements by Gulf Cooperation Council authorities have become increasingly frequent after the revaluation of the Kuwaiti Dinar vis-à-vis the US dollar in May 2006. Likewise, statements by Russian authorities have become increasingly frequent after the introduction of an exchange rate basket including the US dollar and the euro in February 2005. Figures 2.1, 2.2 and 2.3 plot over time the statements by emerging market officials referring to the composition of their foreign reserve assets together with the USD/EUR. It is interesting to note that statements became significantly more frequent after 2004, when the size of emerging market reserve assets started to grow considerably.

\section{Empirical findings}

We now turn to the empirical analysis and the findings. We start by outlining the benchmark results and discuss their economic significance (section 3.1) before testing their robustness and presenting various extensions and modifications to the benchmark (section 3.2).

\subsection{Benchmark model and results}

As outlined in detail above, our primary interest is in understanding how statements by EME officials affect major currencies, and in particular the euro and the yen vis-à-vis the US dollar. Our starting point is the microstructure literature of FX markets, and more specifically the literature on announcement effects and asset prices (e.g. Andersen et al. 2003, Ehrmann and Fratzscher 2005). This literature commonly models the exchange rate in a standard asset-pricing framework, where the log exchange rate $s_{t}$ is a function of the discounted value of private sector expectations about future fundamentals $f_{t+i}$ :

$$
s_{t}=(1-\theta) \sum_{i=0}^{\infty} \theta^{i} E_{t}\left(f_{t+i} \mid \Omega_{t}\right)
$$

with $\Omega_{t}$ as the public information available at time $t$, and $\theta$ as the discount factor. Since our objective is to understand the effect of public statements by policy-makers on exchange rates, we follow the announcement literature and formulate a dynamic specification of the model. Such a dynamic specification of the model yields

$$
r_{t}=(1-\theta) \sum_{i=0}^{\infty} \theta^{i}\left[E_{t}\left(f_{t+i} \mid \Omega_{t}\right)-E_{t-1}\left(f_{t+i} \mid \Omega_{t-1}\right)\right]
$$

with $r_{t}=s_{t}-s_{t-1}$. The implication is that what drives exchange rates are changes to expectations by market participants about relevant future fundamentals. Reserve 
diversification and changes in the exchange rate regime of EMEs and oil exporting countries may precisely be such fundamentals, and the objective of the paper is to test for their empirical relevance for major currency configurations. From this simple, stylized conceptual framework, we derive our empirical model as

$$
r_{t}=\alpha+\beta^{e} S_{t}^{e}+\beta^{r e s} S_{t}^{r e s}+\sum_{k} \chi^{k} X_{t}^{k}+\varepsilon_{t}
$$

with $r_{t}$ as daily exchange rate returns over January 2000-December 2007, $S^{e}$ a [-1; 0; $+1]$ indicator variable for statements on exchange rate regimes, $S^{\text {res }}$ a corresponding indicator variable for communications on reserves, and $X$ a vector of controls including statements by G3 authorities and day-of-the-week effects in the benchmark, and later also macroeconomic news and other controls in the extended specifications.

Daily return data exhibit strong heteroskedasticity, which we correct for by using robust standard errors. In one of the robustness tests discussed in section 3.2, we also model exchange rate returns using an EGARCH specification, i.e. in which we model both the conditional mean and the conditional variance of exchange rate returns. However, as our main interest is in the conditional mean of currency returns, estimating the mean equation via OLS with robust standard errors is sufficient for our purpose.

\section{Table 2}

Table 2 shows the benchmark results when pooling all EME statements, i.e. those on exchange rates and on reserves, into a single variable so that $S=S^{e}+S^{\text {res }}$. There are two main results worth emphasising. The first one is that statements by EMEs matter, as they clearly have a statistically significant effect on the euro and on the yen vis-à-vis the US dollar. On average, a statement by EME officials moves the euro by $0.25 \%$ and the yen by $0.15 \%$ against the US dollar. It is hard to gauge whether these effects are sizeable. One possible interpretation for why the effects on the euro are larger than on the yen is that a larger share of reserve diversification may go into euro denominated assets than in yen denominated assets, and market participants may correctly anticipate this fact.

One way to compare them is with corresponding statements by officials of the US, the euro area and Japan. Models (1) and (3) of Table 2 indicate that the effect of EME statements are indeed comparable in magnitude to those of G3 officials, bar the US. ${ }^{8}$ Models (2) and (4) use as controls only the statements by the main G3 policymakers in charge of exchange rate policy (the US Treasury Secretary, the ECB

\footnotetext{
${ }^{8}$ In fact, statements by US authorise are barely ever statistically significant. This is in line with the literature, which explains the small or negligible effect of US statements by the fact that US policymakers tend to repeat their standard mantra advocating a strong dollar policy, thereby providing no new information to markets. Their statements thus tend to have a small effect, except when US officials deviate from this mantra (see e.g. Fratzscher 2008c).
} 
President, and the Japanese Minister of Finance). The point estimates of EME statements basically remain unchanged, underlining their robustness.

An important point to note at this juncture concerns the permanence of the effects of EME statements. The contemporaneous effects, as presented in Table 2, are meaningful for the relevance of such statements only to the extent that they are lasting or permanent. Extending this model to a dynamic specifications shows that all of the effect of EME statements on exchange rates takes place on the same day, while coefficients for lagged effects are always statistically insignificant. In line with the findings of the microstructure literature, this implies that the contemporaneous effects can indeed be interpreted as the overall, lasting effects of such events.

A second finding is that the effect of EME statements tends to be substantially larger on the euro than on the yen. This is also confirmed when analysing the reaction of the three G3 nominal effective exchange rates in models (5)-(7) of Table 2. Interestingly, the strongest reaction among the effective exchange rates is for the US dollar, which depreciates on average by around $0.11 \%$ in response to EME statements about relaxing their link to the US currency. This seems quite a sizeable effect considering that many EMEs continue to have managed or fixed exchange rates against the US dollar.

Figures $3-4$

A crucial issue is to what extent these estimates are economically meaningful. In particular, how much of the euro and yen movements against the US dollar can be explained by EMEs and their intentions to loosen their US dollar peg and diversify their reserves out of US dollars? To gauge this economic relevance, and given the point on the lasting effect of such statements as argued above, we cumulate the estimated daily effects of EMEs over a time horizon of one year. Figure 3 shows these cumulated effects by year, also distinguishing between and comparing the overall impact of China with that of oil exporting countries (GCC countries plus Russia) and other EMEs. The figure shows a striking increase in the cumulated effect of EMEs on the US dollar - euro exchange rate since 2002. In fact, the largest overall effect was registered in 2006, when statements by all EMEs combined contributed to a 7 percentage point (p.p.) appreciation of the euro against the US dollar. This compares to an actual appreciation of the euro against the US dollar by about $10 \%$, as indicated by the black bars in the figure. ${ }^{9}$

This suggests that EME communication has indeed exerted a sizeable overall effect on the euro exchange rate. Interestingly, the cumulated effect declined somewhat in 2007, but was still about 4 p.p. What explains these time variations? Figure 4 shows the distribution of EME statements, and their inclinations, over time.

\footnotetext{
${ }^{9}$ A further interesting feature of the figure is that in 2006 the effect of GCC statements was overall larger than those of Chinese authorities. This does not necessarily mean that the GCC economies are more important than the Chinese for global and G3 exchange rate configurations. It only means that the new information provided by GCC countries about their intentions regarding reserves and FX regimes may have been much larger than the new information provided by the Chinese, who had embarked on a steady and gradual process of RMB appreciation vis-à-vis the US dollar in July 2005.
} 
It stresses that the frequency of EME statements has continuously increased over time, reaching a peak in 2006. However, after 2006 the content of EME communication appears to have changed markedly, as EME policy-makers became increasingly neutral in their statements, speaking much less frequently about abandoning their US dollar peg or of diversifying reserves away from the US dollar, while stressing more often their desire to maintain their US dollar link. This might reflect a much more cautious communication of EMEs, possibly due to the increased pressure on their currency pegs from capital inflows and expectations about currency reform. ${ }^{10}$

These figures illustrate the potency but also the limitations of our empirical approach. The fact that EME policy-makers have stressed less frequently their desire to alter their exchange rate regimes and reserve composition could either mean that their preferences have changed, or it could imply that they still have the same views but have become more cautious in their communication. If this second possibility is true, we would be able to capture only a smaller share of the true overall impact of EMEs regime changes and portfolio changes. As such, the cumulated effects shown in Figure 3 would therefore constitute a lower bound. ${ }^{11}$

\subsection{Extensions and robustness}

How robust are these findings? There are many potential caveats and limitations to these estimates, and it is imperative to gauge how sensitive the results when trying to address some of these caveats.

A first caveat is that many other pieces of information become available and influence bilateral currency values. It is obviously impossible to include all factors, but we can try to control for relevant US macroeconomic announcements, which have been shown in the literature to exert a significant effect on major currencies against the US dollar (e.g. Andersen et al. 2003). Table 3 shows the findings for two such robustness checks. Models (1) and (3) for the bilateral exchange rates, and (5)-(7) for the effective ones, show the results with these macroeconomic news included and confirm that the point estimates of EME statements remain hardly changed. Moreover, the same holds when including also actual interventions since 2000 by Japanese authorities (as in models (3) and (4) of Table 3). ${ }^{12}$

\footnotetext{
${ }^{10}$ An alternative explanation - which draws from recent market comments on the possible existence of a negative correlation between US dollar movements and oil prices since early 2008 - might be that GCC economies refrain from making statements that could adversely impact the US dollar and thereby possibly reduce their oil revenues.

${ }^{11}$ We have also tested for time variations in the coefficient estimates in the benchmark model. There indeed seems to be an overall increase in the point estimate of EME statements on the euro and the yen over time. However, the magnitude of this change is relatively modest, in particular in later years, so that our preferred calculations of the contributions are based on constant parameter estimates.

${ }^{12} \mathrm{We}$ also included lagged terms of the statements to assess how persistent their impact on major currencies is. As expected, we find that lags are statistically insignificant. This suggests that the information content of statements is priced in by markets immediately on the day they occur, in line with the efficient market hypothesis. Thus we interpret the contemporaneous effects of the statements as the permanent effects.
} 
A second issue is how robust the findings are to alternative classifications. For this purpose, we reclassify all "neutral" statements (i.e. $S=0$ ) into variables that go against the common policy mantra. For instance, a statement of a Japanese official which is neutral but comes in a period when the predominant policy stance is to weaken the yen - as e.g. occurred in most of 2002-04 - would code, under the alternative classification, as a deviation from the common policy mantra and thus as $S$ $=+1$. Models (2) and (4) of Table 3 provide the estimates, but again show that the main findings hold, although the point estimates are somewhat smaller.

Tables $3-7$

As a further extension, we next split EME statements into those that talk about the exchange rate regime of the respective countries and those that discuss reserve diversification. Table 4 shows this split for all EMEs combined, while Tables 5-7 provide the corresponding estimates individually for Chinese, GCC and Russian officials, respectively. Table 4 indicates that the effect of EME statements is very similar when officials communicate about the exchange rate regime or reserves.

However, Tables 5-7 indicate that there are some differences across countries. For China, it seems that markets react primarily to statements about the exchange rate regime, and not to those about reserve diversification. By contrast, there is no sizeable difference across categories of statements for GCC countries or Russia. The lack of significance of Chinese statements on reserves may partly stem from the fact that Chinese officials hardly ever openly talk about reserve diversification, and possibly that market participants expect this to be a less pressing issue than the future of China's domestic exchange rate regime, which has been the main focus of international discussions thus far.

\section{Tables $8-9$}

We also test the impact of statements by emerging Asian authorities other than China, which mainly focus on reserve diversification, and find similar results for the dollar-euro (but no statistically significant impact on the dollar-yen). Moreover, we tested the impact of statements made by authorities of countries like Iraq, Iran, North Korea or Venezuela, which have switched, or signalled their intention to do so, part of their international transactions (e.g. oil sales) or foreign reserves in euros. We find that these statements have no significant impact on either the currency pairs or the effective exchange rates, cautiously suggesting that markets may not react to changes in currency focus driven by political considerations, but mainly to those driven by economic ones.

We next turn to other robustness checks. The first one, shown in Table 8, is the question as to whether EME communication affects not only the level, but also the conditional volatility of the euro, the yen and the US dollar. Table 8 shows the estimates from an EGARCH $(1,1)$ model specification in which we test the effect of EME statements also on the conditional variance of daily currency returns. The findings are in line with those of the literature on foreign exchange communication in 
that EME statements tend to lower market volatility (e.g. Fratzscher 2008c), suggesting that such statements are considered help reduce uncertainty and settle markets.

As a further robustness check, we also test the impact of emerging market statements on their own domestic currencies. However, given that these currencies remain pegged or heavily managed, we use 1-year non-deliverable forward rates (NDFs) instead. ${ }^{13}$ We find some evidence that Chinese statements also matter for its domestic currency NDF, but not for the other NDFs. However, giving a meaningful interpretation to such results is difficult given the tight management of these currencies.

A further issue is the overall goodness-of-fit of our empirical model. How much of the daily euro, dollar and yen fluctuations can actually be explained by this model? Table 9 shows the $R$-squared of partial models in which the models are estimated only for those days when policy-makers in individual economies issued statements, as compared to all days. For instance, focusing on the US dollar-euro shows that EME statements can explain about $15 \%$ of the daily variation of this currency pair on days when EME officials issued statements. The explanatory power of different groups and different currencies varies. However, while such magnitude of the $R$-squared may not sound very large, it still appears quite sizeable given the overall volatility of exchange rates (see e.g. Andersen et al. 2003).

\section{Tables $10-11$}

As the final part, we would like to understand better the channels and the conditions under which EME communication influences major currency configurations. One hypothesis is that FX markets are more sensitive to new information when there is large uncertainty or when currency misalignments are large. Distinguishing between periods with high versus low market volatility (relative to the sample average for the corresponding 1-month historical volatility), the estimates shown in Table 10 suggest that EME communication has not a significantly larger effect in periods of high market volatility relative to periods of low market volatility. However, distinguishing between periods of large versus small misalignments (defined here as periods when the exchange rate deviates from its 5-year historical average), the estimates show a larger effect on the US dollar - euro exchange rate when currency misalignments are large.

Similarly, Table 11 indicates that the effect of EME statements is larger when market expectations of an impending change in the respective countries' currency regime is perceived to be relatively likely, based on expectations proxied by forward contracts. Indeed, interacting statements by emerging economies with the expected change in the Chinese renminbi relative to the US dollar, proxied here by using the difference between the 1-year NDFs and the spot rate, the impact of these statements is shown to be more than twice larger when markets expect the renminbi to appreciate. Conversely, we do not find that the impact is larger when using NDFs for

\footnotetext{
${ }^{13}$ Results are not shown here to save space but are available from the authors upon request.
} 
the currencies of the Gulf Cooperation Council, perhaps because these are less liquid instruments with more limited information content on market expectations than renminbi NDFs. Still, the results are somewhat supportive of the expectations channel, as the effect of a given statement is larger when also market expectations about a future change in the domestic currency regime of China increase.

\section{Conclusions}

The empirical findings of the paper suggest that statements by systemically important EMEs - such as China, the GCC countries and Russia - have a sizeable impact on major currency configurations. In particular, it appears that it is in particular the euro that is highly sensitive to indications by EMEs to abandon their close US dollar focus in their exchange rate regime or in their reserve management. The US dollar-yen exchange rate is also found to be sensitive to such statements, but significantly less so than the euro. In turn, the US dollar nominal effective exchange rate tends to depreciate when such statements occur. These findings are robust to a battery of extensions and alternative specifications of the model.

Moreover, EMEs statements about their intention to move away from a close US dollar focus do not only exert a statistically significant but also an economically meaningful impact on major currency configurations. Cumulating the effects on an annual basis suggest that since 2003/04, statements by EME officials and ensuing market expectations contributed a substantial share to the overall appreciation of the euro against the US dollar, and possibly as much as 7 percentage points in 2006 alone. Interestingly, the effect of EMEs on global exchange rate configurations also seems to have declined markedly in 2007. This might reflect the much more cautious communication of EMEs, possibly due to the increased pressure on their currency pegs from capital inflows and expectations about currency reform.

Many caveats and limitations apply to our empirical approach, in particular as the statements we analyse may capture only a fraction of the true effect of EME currency and reserve choices on global exchange rate configurations. However, given their rising importance, it is intriguing and important to understand how these economies are affecting major currency configurations. We have conducted a broad battery of extensions and modifications to the benchmark model, and find that overall the empirical findings appear robust. Overall, the strength of the approach is a clean identification of factors that are specific to EMEs, which in turn allows us to gauge how a future shift away from the US dollar may alter the global setting and role of different currencies, in particular the US dollar, the euro and the yen.

The findings of the paper have a number of policy implications. As a first one, our empirical results clearly stress that important EMEs, such as China, Russia and the GCC economies, have a systematic and sizeable impact on global exchange rate configurations. In particular given the magnitude of the reserves held by these countries, any shift in market expectations that one or several of these countries could loosen their close US dollar focus or diversify reserves affects also the major currency 
pairs, and in particular the euro. The results obviously do not contain any implications about what an optimal exchange rate regime choice is for these economies. But the findings suggest that policy-makers in these economies are increasingly becoming aware of the impact of their statements on global financial markets. This underlines that communication can be an important and effective policy tool that needs to be used with caution and with a clear idea of what it aims to achieve. 


\section{References}

Andersen, T., Bollerslev, T., Diebold, F. Diebold and Vega, C. (2003). 'Micro Effects of Macro Announcements: Real-Time Price Discovery in Foreign Exchange', American Economic Review, vol. 39(1), pp. 38-62.

Beine, M., G. Janssen, and C. Lecourt. (2006). 'Should Central Bankers Talk to the FX Market?' unpublished, available at http://homepages.ulb.ac.be/ mbeine/

Blinder, A., Ehrmann, M., de Haan, J., Fratzscher, M., and Jansen D.-J. 2008 'Central Bank communication and monetary policy: a survey of theory and evidence', Journal of Economic Literature, forthcoming.

Branson, W. H. (1977). 'Asset Markets and Relative Prices in Exchange Rate Determination', Sozialwissenschaftliche Annalen, Band 1.

Dominguez, K., and J. Frankel (1993). 'Does Foreign Exchange Intervention Matter? The Portfolio Effect.' American Economic Review, 83(5): 1356-69.

Dominguez, K., and F. Panthaki (2007). 'The Influence of Actual and Unrequited Interventions.' International Journal of Finance and Economics, 12(2): 171-200.

Égert, B. (2007). 'Central bank interventions, communication and interest rate policy in emerging European economies,' Journal of Comparative Economics 35: 387413.

European Central Bank (2008). 'The use of the euro in global foreign exchange reserves', Review of the international role of the euro, Frankfurt am Main.

Fratzscher, M. (2008a). 'Oral Interventions versus Actual Interventions in FX Markets-An Event-Study Approach', Economic Journal July 2008.

Fratzscher, M. (2008b). 'How Successful is the G7?', mimeo, June 2008.

Fratzscher, M. (2008c). 'Communication and Exchange Rate Policy', ECB Working Paper No. 363, forthcoming Journal of Macroeconomics.

Greenspan, A. (2004). 'Current Account', Remarks by Chairman Greenspan before the Economic Club of New York on 2 March 2004 (http://www.federalreserve.gov/boarddocs/speeches/2004/20040302/default.htm.

Jansen, D.-J. and J. de Haan. (2005). 'Talking Heads: The Effects of ECB Statements on the Euro-Dollar Exchange Rate', Journal of International Money and Finance, vol. 24(2), pp. 343-361.

Jansen, D.-J., and J. de Haan. (2007). 'Were Verbal Efforts to Support The Euro Effective? A High-frequency Analysis of ECB Statements.' European Journal of Political Economy, 23(1): 245-259.

Nelson, D. (1991). 'Conditional Heteroskedasticity in Asset Returns: A New Approach', Econometrica, 59:2, pp. 347-70.

Reitz, S, and Taylor, M. (2006). 'The coordination channel of foreign exchange intervention: a nonlinear microstructural analysis', Working Paper, Deutsche Bundesbank.

Sarno, L. and Taylor, M. (2001). 'Official Intervention in the Foreign Exchange Market: Is it Effective and, If So, How Does it Work?', Journal of Economic Literature, vol. 39, pp. 839-868.

Siklos, P. L. and M. T. Bohl. 'Policy Words and Policy Deeds: The ECB and the Euro', International Journal of Finance and Economics, forthcoming. 
Taylor, M. (2004). 'Is official exchange rate intervention effective?', Economica, vol. 71: pp. $1-11$. 


\section{Appendix I: list of the policy-makers included in the database}

\section{$\underline{\text { US Treasury }}$}

\section{US Treasury Secretary}

- $\quad$ Lloyd M. Bentsen: 20 January 1993 - 22 December 1994

- $\quad$ Robert E. Rubin: 11 January 1995 - 2 July 1999

- $\quad$ Lawrence H. Summers: 2 July 1999 - 20 January 2001

- $\quad$ Paul H. O'Neill: 20 January 2001 - 31 December 2002

- John W. Snow: 3 February 2003 - 30 June 2006

- $\quad$ Henry M. Paulson: 10 July 2006 - present

US Treasury Deputy Secretary

- $\quad$ Robert E. Rubin: 20 January 1993 - 22 December 1994

- $\quad$ Lawrence H. Summers: 11 January 1995 - 2 July 1999

- $\quad$ Stuart E. Eizenstat: 2 July 1999 - 20 January 2001

- $\quad$ Kenneth W. Dam: 20 January 2001 - 31 December 2002

- $\quad$ Samuel W. Bodman: 17 February 2004 - 31 January 2005

- $\quad$ Robert M. Kimmit: 16 August 2005 - present

\section{Federal Reserve Board of Governors}

\section{Chairman}

- $\quad$ Alan Greenspan: 11 August 1987 - 31 January 2006

- $\quad$ Ben Bernanke: 1 February 2006 - present

Current Members of the Board

- $\quad$ Donald L. Kohn, Vice Chairman

- Kevin M. Warsh

- $\quad$ Randall S. Kroszner

- $\quad$ Frederic S. Mishkin

Previous members of the Board: see

http://www.federalreserve.gov/bios/boardmembership.htm

\section{European Central Bank}

\section{President}

- $\quad$ Willem F. Duisenberg: 1 June 1998 - 30 October 2003

- Jean-Claude Trichet: 1 November 2003 - present 
Vice-President

- $\quad$ Christian Noyer, 1 June 1998 - June 2002

- $\quad$ Lucas D. Papademos, June 2002 - present

Other current Members of the Executive Board and the Governing Council

- $\quad$ Lorenzo Bini Smaghi

- José Manuel González-Páramo

- Jürgen Stark

- $\quad$ Gertrude Tumpel-Gugerell

Other current Members of the Governing Council

- $\quad$ Guy Quaden, Governor, Nationale Bank van België/Banque Nationale de Belgique

- $\quad$ Axel A. Weber, President, Deutsche Bundesbank

- John Hurley Governor, Central Bank and Financial Services Authority of Ireland

- $\quad$ Nicholas C. Garganas, Governor, Bank of Greece

- $\quad$ Miguel Fernández Ordóñez, Governor, Banco de España

- $\quad$ Christian Noyer, Governor, Banque de France

- Mario Draghi, Governor, Banca d'Italia

- Athanasios Orphanides, Governor, Central Bank of Cyprus

- $\quad$ Yves Mersch, Governor, Banque centrale du Luxembourg

- $\quad$ Michael C. Bonello, Governor, Central Bank of Malta

- $\quad$ Nout Wellink, President, De Nederlandsche Bank

- $\quad$ Klaus Liebscher, Governor, Oesterreichische Nationalbank

- Vítor Manuel Ribeiro Constâncio, Governor, Banco de Portugal

- $\quad$ Marko Kranjec, Governor, Banka Slovenije

- $\quad$ Erkki Liikanen, Governor, Suomen Pankki - Finlands Bank

\section{$\underline{\text { Ministry of Finance (Japan) }}$}

Minister

- $\quad$ Yoshiro Hayashi: 1992 - 1993

- $\quad$ Hirohisa Fujii: 1993 - 1994

- $\quad$ Masayoshi Takemura: 1994 - 1996

- Wataru Kubo: 1996

- $\quad$ Hiroshi Mitsuzuka: 1996 - 1998

- $\quad$ Hikaru Matsunaga: 1998

- $\quad$ Masajuro Shiokawa: $2001-2003$

- $\quad$ Sadakazu Tanigaki: 2003 - 2006

- $\quad$ Koji Omi: 2006 - 2007

- $\quad$ Fukushiro Nukaga: 2007 - present 


\section{Bank of Japan}

\section{Governor}

- $\quad$ Mr. Yasushi Mieno: 17 December 1989 - 16 December 1994

- $\quad$ Mr. Yasuo Matsushita: 17 December 1994 - 20 March 1998

- $\quad$ Mr. Masaru Hayami: 20 March 1998 - 19 March 2003

- $\quad$ Mr. Toshihiko Fukui: 20 March 2003 - 19 March 2008

- $\quad$ Prof. Masaaki Shirakawa: 9 April 2008 - present

\section{China}

Presidents of the People's Republic of China

- Jiang Zemin: 27 March 1993 - 15 March 2003

- Hu Jintao: since 15 March 2003 - present

List of Premiers of the People's Republic of China

- $\quad$ Li Peng: 1987 - 17 March 1998

- $\quad$ Zhu Rongji: 17 March 1998 - 16 March 2003

- $\quad$ Wen Jiabao: since 16 March 2003

Governor of the People's Bank of China

- $\quad$ Dai Xianglong: June 1995 - December 2002

- Zhou Xiaochuan: December 2002 - present

State Administration of Foreign Exchange (SAFE)

- $\quad$ Various relevant officials

\section{Other emerging Asian economies}

Hong Kong

- $\quad$ Joseph Yam, Chief Executive, Hong Kong Monetary Authority: April 1993 present

India

- $\quad$ Yaga Venugopal Reddy, Governor, Reserve Bank of India: 6 September 2003 - present 
Malaysia

- $\quad$ Mahathir Mohamad, Prime Minister: 16 July 1981 - 31 October 2003

- Zeti Akhtar Aziz, Governor, Bank Negara Malaysia: May 2000 - present

Republic of China (Taiwan)

- $\quad$ Yu Shyi-kun, Premier: 1 February 2002 - 1 February 2005

- Wu Rong-I, Vice Premier

- Hsu Yi-Hsiung, Deputy Governor, Central Bank of the Republic of China (Taiwan): March 1998 - present

Singapore

- Government of Singapore Investment Corp. (GIC), incl. Chairman Lee Kuan Yew

South Korea

- $\quad$ Han Duck-Soo, Minister of Finance: 14 March 2006 - July 2006; Prime

Minister: 9 March 2007 - present

- $\quad$ Park Seung, Bank of Korea, March 2002-March 2006

\section{$\underline{\text { Russian Federation }}$}

Minister of Finance

- $\quad$ Alexei Leonidovich Kudrin: 18 May 2000 - present

Chair of the Central Bank of the Russian Federation

- $\quad$ Viktor Gerashchenko: 1998 - March 2002.

- $\quad$ Sergei Mikhailovich Ignatiev: 20 March 2002 - present

\section{$\underline{\text { Gulf Cooperation Council }}$}

Bahrain

- $\quad$ Rasheed Mohammed Al Maraj, Head, Bahrain Monetary Agency

- $\quad$ Sheikh Ahmed bin Mohammad al-Khalifa, Minister of Finance

Kuwait

- $\quad$ Sheikh Salem Abdul-Aziz al-Sabah, Governor, Central Bank of Kuwait

- Bader al-Humaidhi, Minister of Finance 
- Hamood Sangour al-Zadjali, Executive President, Central Bank of Oman

Qatar

- $\quad$ Abdullah Al-Attiya, Governor, Qatar Central Bank

- $\quad$ Sheikh Abdullah bin Saud al-Thani, Governor, Qatar Central Bank

- $\quad$ Youssef Hussein Kamal, Minister of Finance

Saudi Arabia

- Hamad Saud al-Sayyari, Governor, Saudi Arabian Monetary Agency

- Muhammad Al-Jasser, Vice Governor, Saudi Arabian Monetary Agency

- Ibrahim al-Assaf, Minister of Finance

United Arab Emirates

- $\quad$ Sultan bin Nasser al-Suwaidi, Governor, Central Bank of the United Arab Emirates

\section{Other}

Iran

- Various press reports on Iran's plans to invoice oil in euros and change the composition of central bank reserves

Iraq

- Various senior foreign and Iraqi officials on Iraq's decision to invoice oil in euros and subsequently in dollars

\section{North Korea}

- Reports from China's Xinhua news agency on North Korea's decision to convert dollar-denominated accounts into euro and other currencies

Venezuela

- $\quad$ Hugo Chavez, President: 2 February 1999 - present 


\section{Appendix II: Examples of classification of statements by category}

\begin{tabular}{|c|c|c|c|c|}
\hline \multicolumn{5}{|c|}{ 1. Examples of statements on the exchange rate regime } \\
\hline Market impact & $\begin{array}{l}\text { Dummy } \\
\text { value }\end{array}$ & Time & Policy-maker & Statement \\
\hline US dollar & & 28/08/2005 23:48 GMT & $\begin{array}{l}\text { Governor Zhou } \\
\text { (People's Bank of China) }\end{array}$ & $\begin{array}{l}\text { "I think it is very clear that China is introducing a new exchange rate } \\
\text { mechanism. It is not a one-time adjustment." }\end{array}$ \\
\hline $\begin{array}{l}\text { reference is } \\
\text { relaxed to } \\
\text { appreciate }\end{array}$ & 1 & 13/11/2007 11:19 GMT & $\begin{array}{l}\text { Governor al-Suwaidi } \\
\text { (Central bank of the UAE) }\end{array}$ & $\begin{array}{l}\text { "The dirham's peg to the U.S. dollar has served the economy of the UAE } \\
\text { very well in the past... However, we have reached a crossroads now with a } \\
\text { further deterioration in the U.S. dollar." }\end{array}$ \\
\hline US dollar & & 09/10/2004 03:32 GMT & $\begin{array}{l}\text { Prime Minister Wen Jiabao } \\
\text { (China) }\end{array}$ & $\begin{array}{l}\text { "We will take gradual steps towards building a flexible and resilient } \\
\text { exchange system." }\end{array}$ \\
\hline $\begin{array}{l}\text { reference is } \\
\text { maintained }\end{array}$ & 0 & 24/10/2006 04:59 GMT & $\begin{array}{l}\text { Governor Hamad Saud al- } \\
\text { Sayyari (Saudi Arabian } \\
\text { Monetary Agency) }\end{array}$ & "There is no intention to change the exchange rate." \\
\hline $\begin{array}{l}\text { US dollar } \\
\text { reference is } \\
\text { relaxed to } \\
\text { depreciate }\end{array}$ & -1 & 08/05/1998 02:10 GMT & $\begin{array}{l}\text { Governor Dai } \\
\text { (People's Bank of China) }\end{array}$ & $\begin{array}{l}\text { "We still have enough confidence to say we will be able to maintain a stable } \\
\text { currency...It goes without saying that China has to pay a certain price to } \\
\text { maintain a stable renminbi." }\end{array}$ \\
\hline \multicolumn{5}{|c|}{ 2. Examples of statements on reserve composition } \\
\hline Market impact & $\begin{array}{l}\text { Dummy } \\
\text { value }\end{array}$ & Time & Policy-maker & Statement \\
\hline \multirow{2}{*}{$\begin{array}{l}\text { Diversification } \\
\text { out of the US } \\
\text { dollar }\end{array}$} & \multirow{2}{*}{1} & 08/01/2002 13:32 GMT & $\begin{array}{l}\text { Finance Minister Xiang } \\
\text { Huaicheng (China) }\end{array}$ & $\begin{array}{l}\text { "China has always thought the euro important and thinks that it will some } \\
\text { day be on an equal footing with the U.S. dollar. It is inevitable that the euro } \\
\text { will become some countries' reserve currency." }\end{array}$ \\
\hline & & 11/07/2005 17:21 GMT & $\begin{array}{l}\text { Governor al-Suwaidi } \\
\text { (Central bank of the UAE) }\end{array}$ & $\begin{array}{l}\text { "The euro has declined a lot and it is tempting to buy... if they see it's } \\
\text { tempting, they might say, 'OK, why don't you put } 5 \text { percent in euros?"' }\end{array}$ \\
\hline $\begin{array}{l}\text { Reserve } \\
\text { composition is } \\
\text { maintained }\end{array}$ & 0 & 24/03/2005 11:52 GMT & $\begin{array}{l}\text { Deputy chief of SAFE Wei } \\
\text { Benhua (China) }\end{array}$ & $\begin{array}{l}\text { "When managing our foreign exchange reserves, we insist on the principle of } \\
\text { safety, liquidity and profitability." }\end{array}$ \\
\hline \multirow{2}{*}{$\begin{array}{l}\text { Diversification } \\
\text { into the US } \\
\text { dollar }\end{array}$} & \multirow[b]{2}{*}{-1} & 05/03/2006 01:25 GMT & $\begin{array}{l}\text { Governor Zhou } \\
\text { (People's Bank of China) }\end{array}$ & $\begin{array}{l}\text { "The forex reserves are still growing. Some people are concerned that the } \\
\text { amount of dollar assets in the reserves will fall. But that is not the case." }\end{array}$ \\
\hline & & 10/04/2005 10:46 GMT & $\begin{array}{l}\text { Governor Park Seung } \\
\text { (Bank of Korea) }\end{array}$ & $\begin{array}{l}\text { Korea "would not seek to diversify currencies in its foreign reserves away } \\
\text { from the dollar because that would push the won higher." }\end{array}$ \\
\hline
\end{tabular}

Source: authors' database. 


\section{Charts}

Figure 1.1: USD/EUR and Chinese statements on their US dollar peg

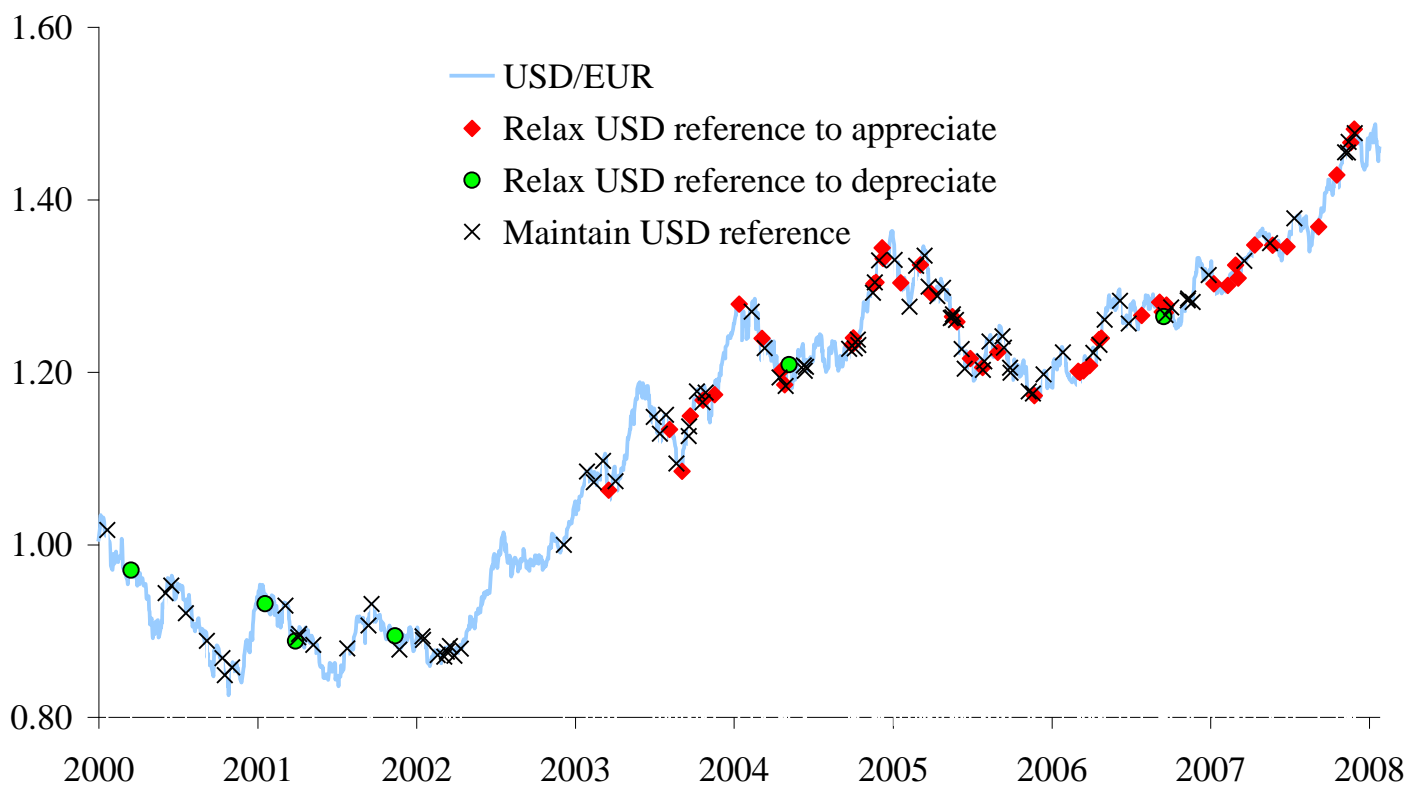

Source: Bloomberg and authors' database.

Figure 1.2: USD/EUR and oil exporters' statements on their USD peg

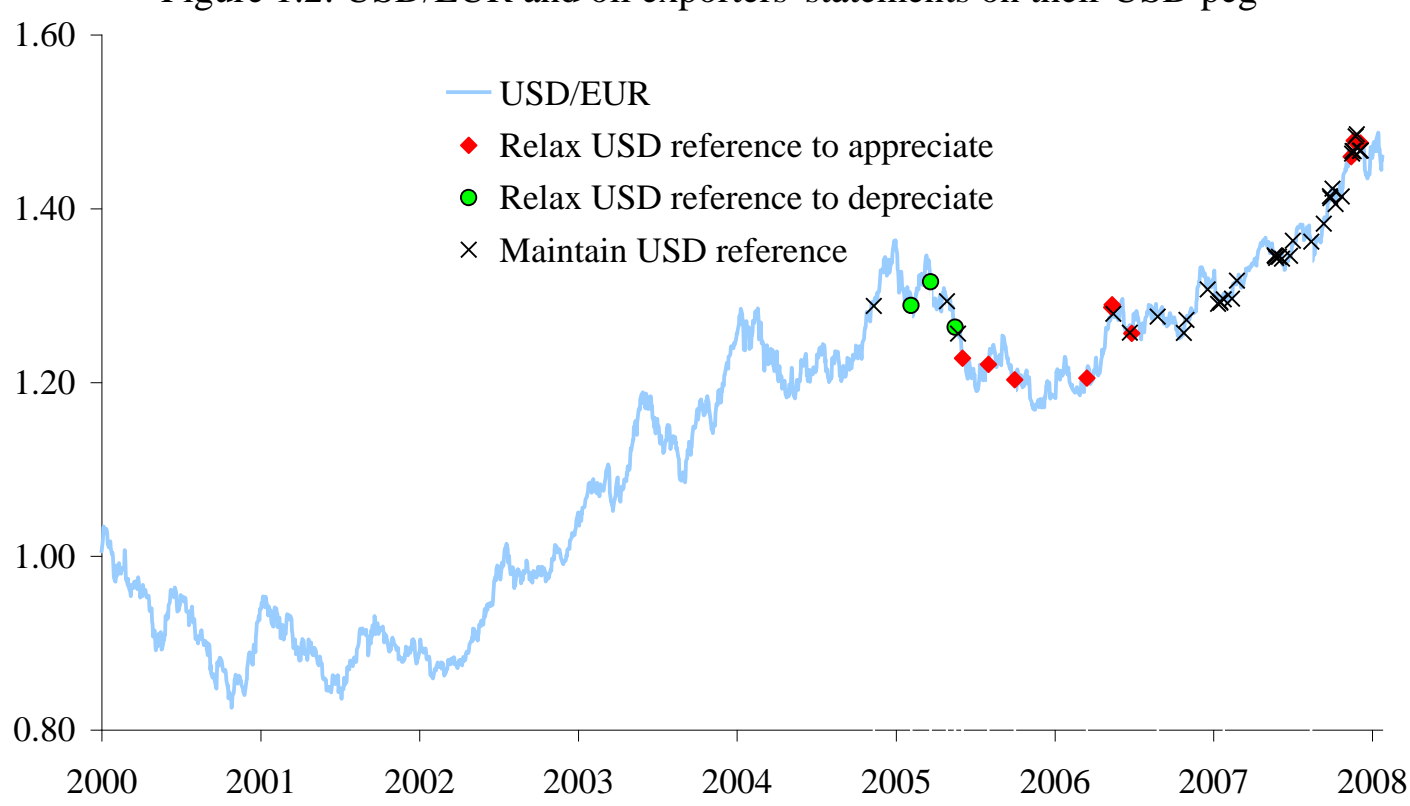

Source: Bloomberg and authors' database. 
Figure 2.1: USD/EUR and Chinese statements on reserves

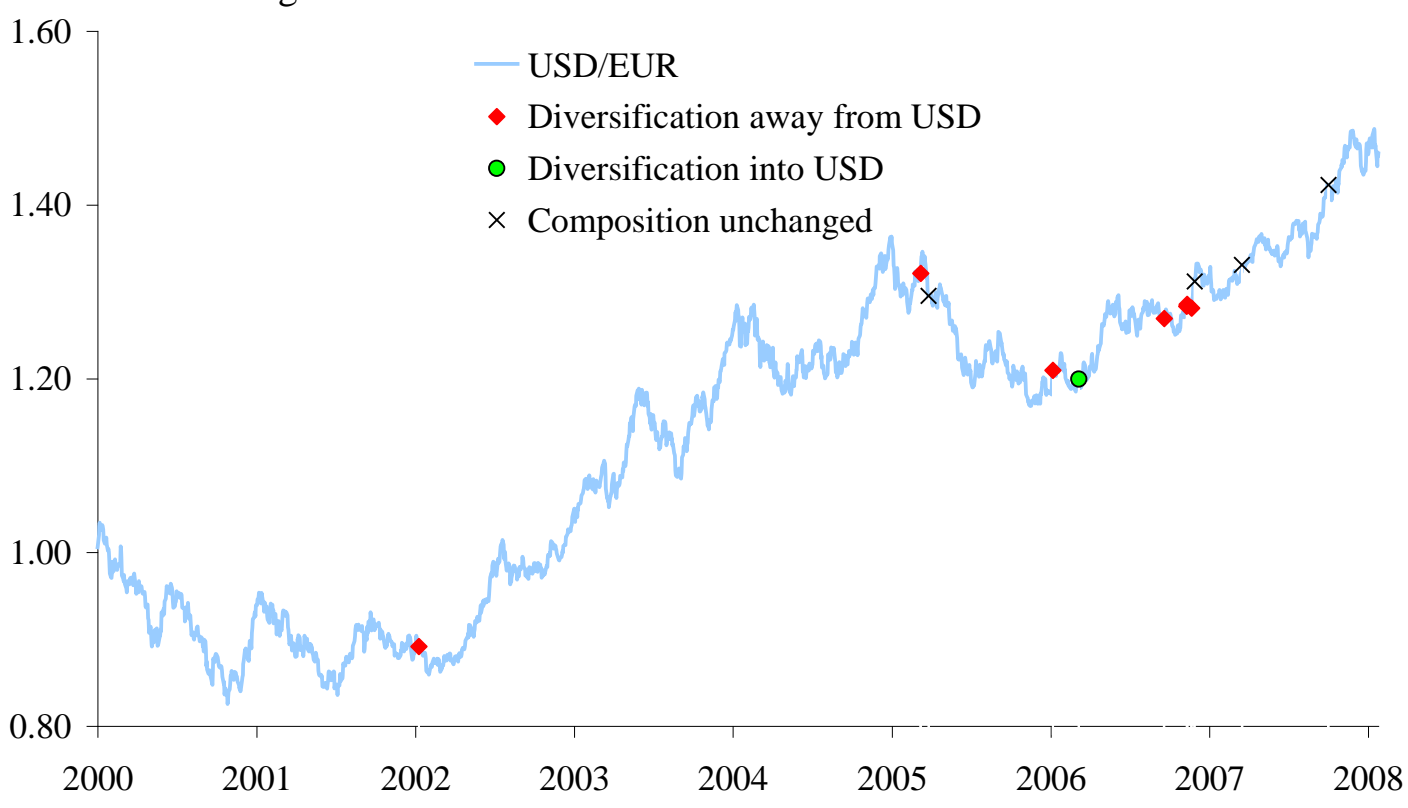

Source: Bloomberg and authors' database.

Figure 2.2: USD/EUR and oil exporters statements on reserves

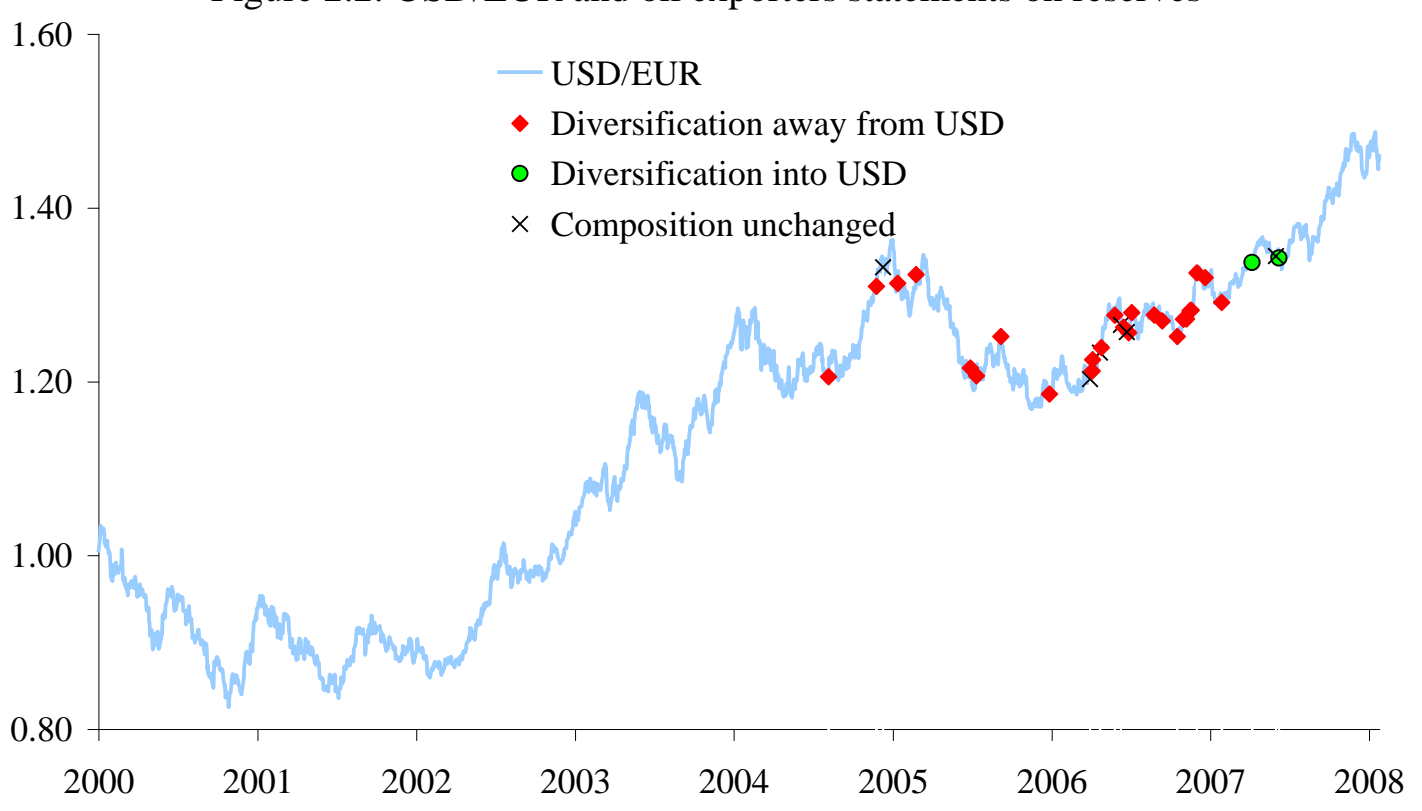

Source: Bloomberg and authors' database. 
Figure 2.3: USD/EUR and other emerging Asian statements

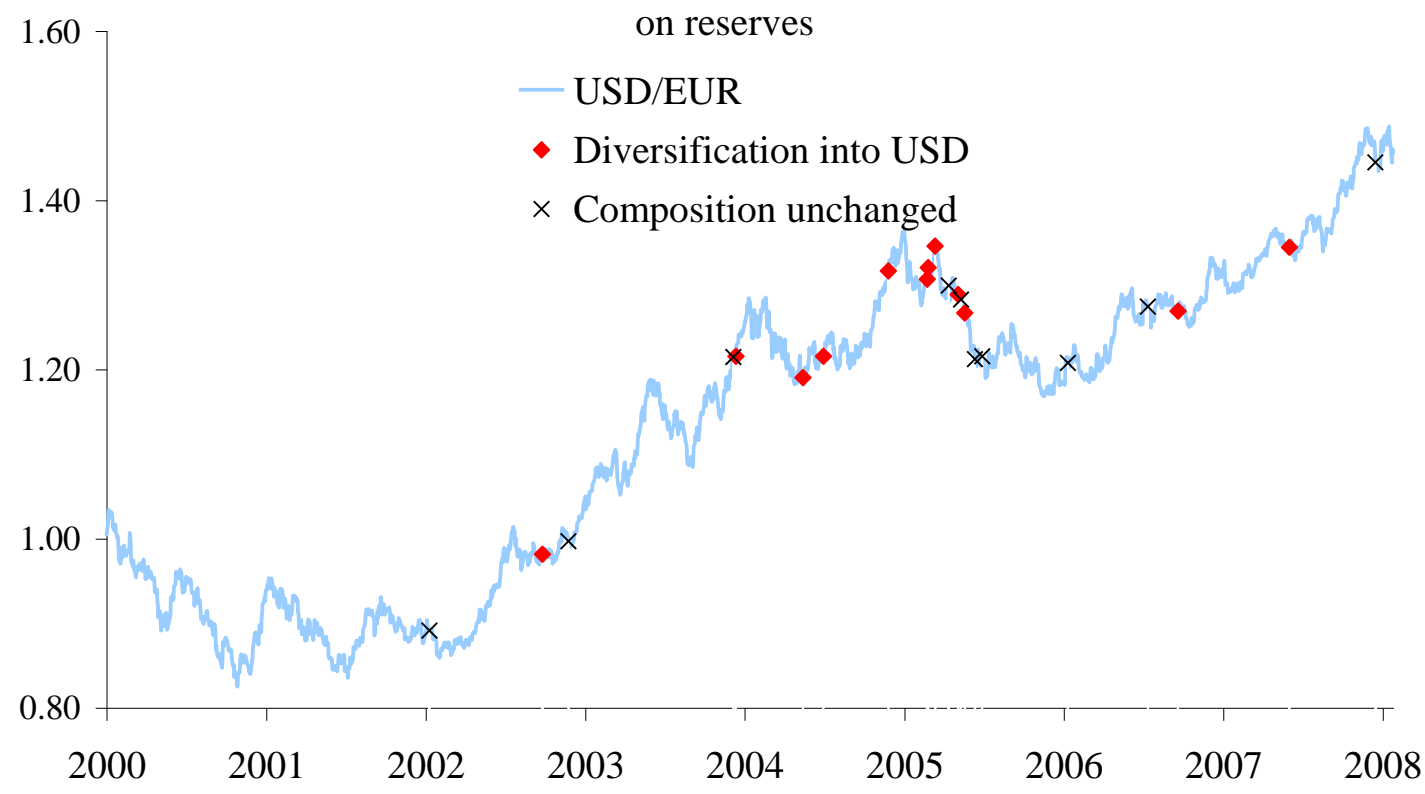

Source: Bloomberg and authors' database. 
Figure 3: Cumulated impact of EME statements on USD/EUR exchange rate change per annum

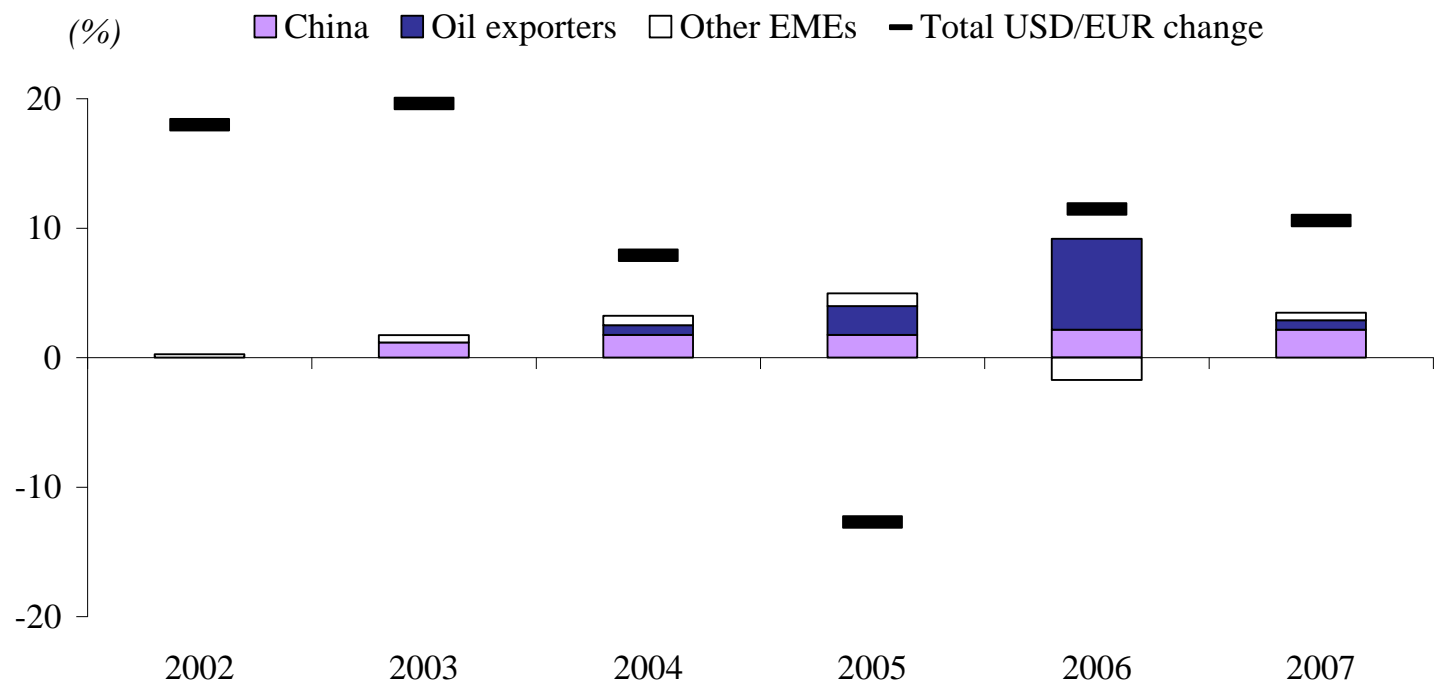

Source: Bloomberg and authors' estimates.

Figure 4: Number of statements (all emerging economy policy-makers)

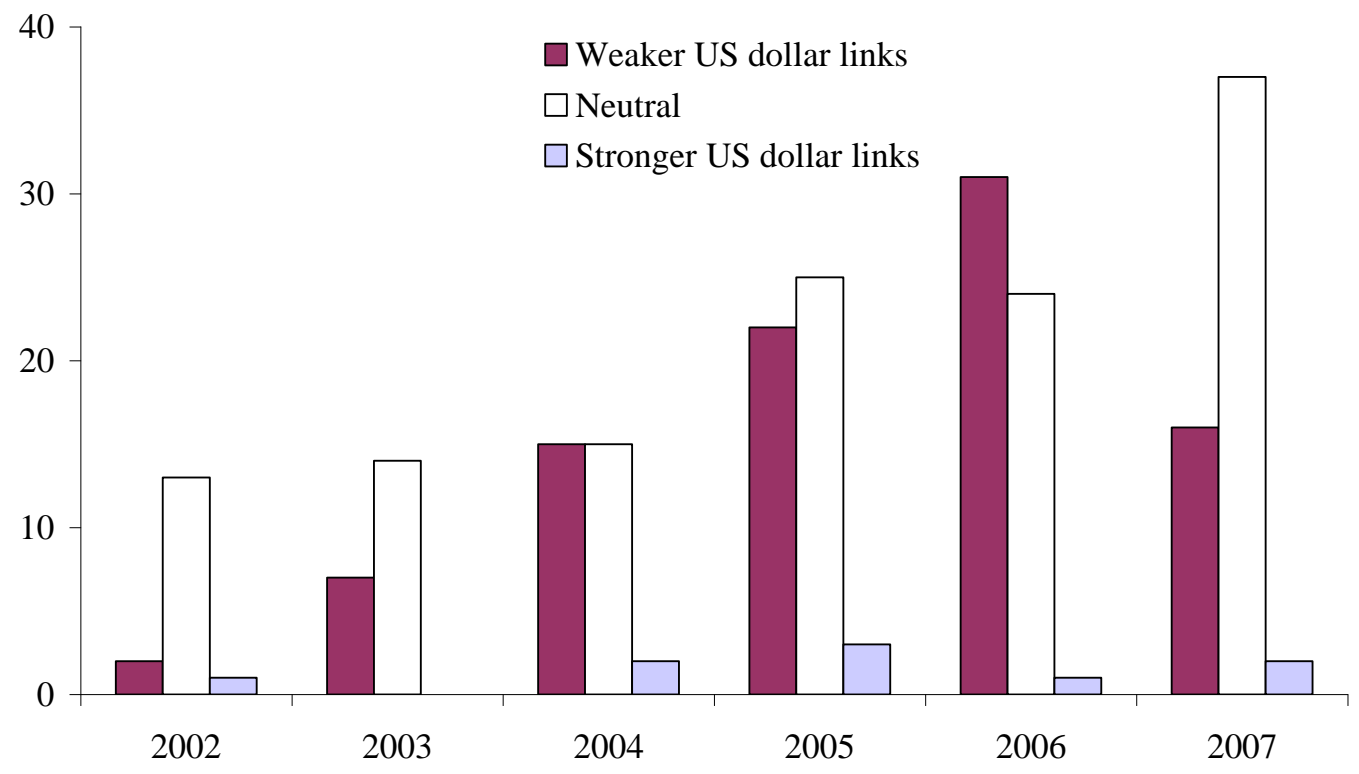

Source: authors' database. 
Figure 5.1: Difference between spot and 1-year forward RMB/USD

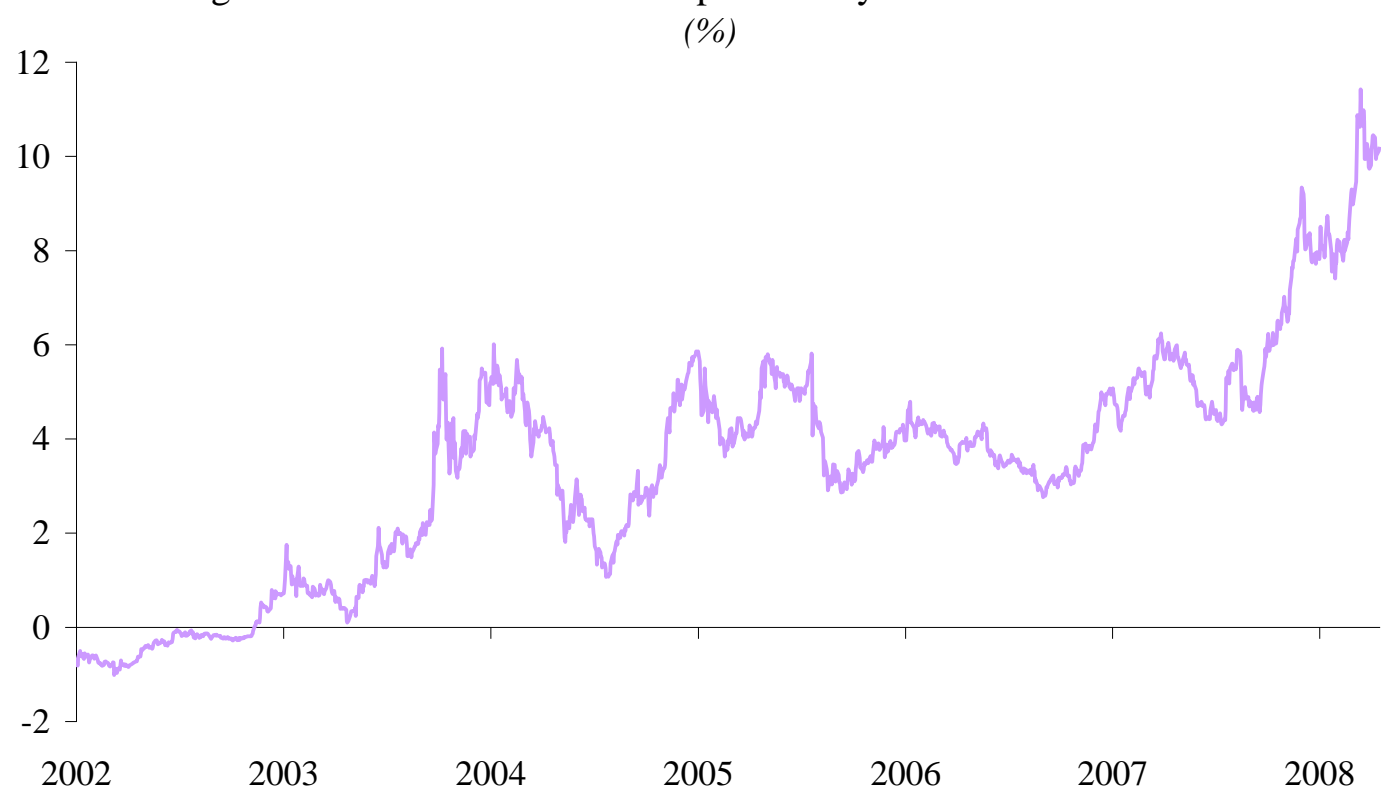

Source: Bloomberg and authors' calculations.

Figure 5.2: Difference between spot and 1-year forward vs. USD

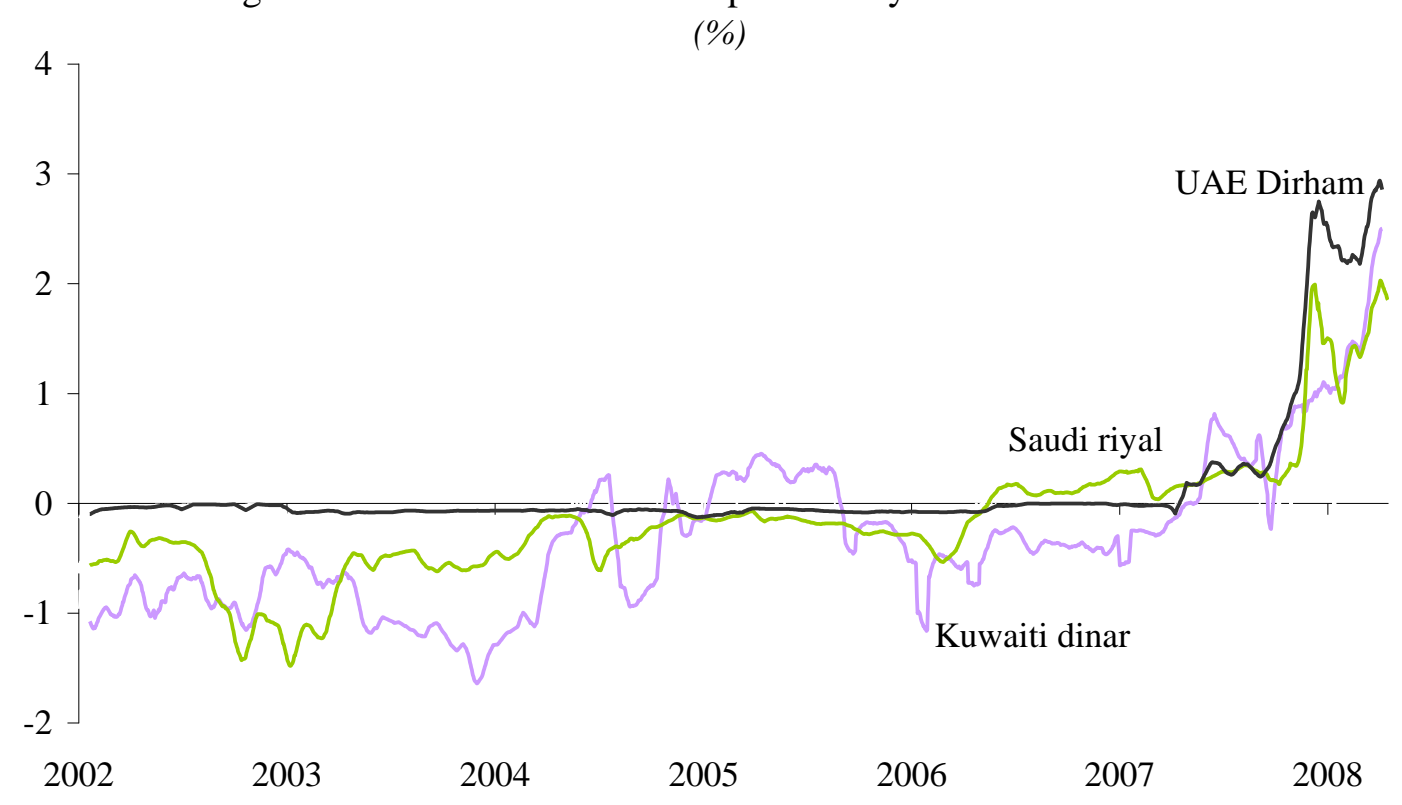

Source: Bloomberg and authors' calculations. 


\section{Tables}

Table 1.1: Number of statements by emerging market officials on exchange rate regime

\begin{tabular}{|c|c|c|c|c|}
\hline & \multirow[t]{2}{*}{ All statements } & \multicolumn{3}{|c|}{ of which: } \\
\hline & & $\begin{array}{r}\text { Relax USD } \\
\text { reference to } \\
\text { appreciate }\end{array}$ & $\begin{array}{r}\text { Relax USD } \\
\text { reference to } \\
\text { depreciate }\end{array}$ & $\begin{array}{r}\text { Maintain } \\
\text { USD } \\
\text { reference }\end{array}$ \\
\hline Chinese authorities & 149 & 48 & 6 & 95 \\
\hline$o / w:$ PBC President & 105 & 31 & 4 & 70 \\
\hline Other emerging Asia authorities & 1 & 0 & 1 & 0 \\
\hline Russian authorities & 12 & 4 & 3 & 5 \\
\hline GCC authorities & 37 & 6 & 0 & 31 \\
\hline All emerging market authorities & $\overline{199}$ & $\overline{58}$ & $\overline{10}$ & 131 \\
\hline
\end{tabular}

Source: authors' own compilation and calculations.

Sample period: January 2000-December 2007.

Table 1.2: Number of statements by emerging market officials on reserve composition

\begin{tabular}{|c|c|c|c|c|}
\hline & All statements & \multicolumn{3}{|c|}{ of which: } \\
\hline & & $\begin{array}{l}\text { Diversification } \\
\text { away from USD }\end{array}$ & $\begin{array}{r}\text { Diversification } \\
\text { into USD }\end{array}$ & $\begin{array}{r}\text { Maintain } \\
\text { reserve } \\
\text { composition }\end{array}$ \\
\hline Chinese authorities & 12 & 7 & 1 & 4 \\
\hline Other emerging Asia authorities & 23 & 12 & 1 & 10 \\
\hline Russian authorities & 13 & 6 & 2 & 5 \\
\hline GCC authorities & 20 & 19 & 0 & 1 \\
\hline All emerging market authorities & $\overline{68}$ & $\overline{44}$ & $\overline{4}$ & 20 \\
\hline
\end{tabular}

Source: authors' own compilation and calculations.

Sample period: January 2000-December 2007. 
Table 2: Impact of official statements by emerging economy authorities on G3 exchange rates (1. Jan. 2000 - 31 Dec. 2007)

\begin{tabular}{|c|c|c|c|c|c|c|c|}
\hline & \multicolumn{4}{|c|}{ A. Bilateral exchange rates } & \multicolumn{3}{|c|}{ B. NEERs ${ }^{1)}$} \\
\hline & \multicolumn{2}{|c|}{ USD/EUR } & \multicolumn{2}{|c|}{ USD/JPY } & Euro & US dollar & \multirow{2}{*}{$\frac{\text { Yen }}{(7)}$} \\
\hline & (1) & (2) & (3) & (4) & (5) & (6) & \\
\hline \multirow[t]{2}{*}{ Emerging economy authorities } & $0.245 * * *$ & $0.240 * * *$ & $0.145 * * *$ & $0.142 * * *$ & $0.072 * *$ & $-0.107 * * *$ & 0.051 \\
\hline & $(0.043)$ & $(0.043)$ & $(0.055)$ & $(0.055)$ & $(0.028)$ & $(0.041)$ & $(0.049)$ \\
\hline \multirow[t]{2}{*}{ All euro area authorities } & $0.191 * * *$ & & 0.068 & & & & \\
\hline & $(0.059)$ & & $(0.056)$ & & & & \\
\hline \multirow[t]{2}{*}{ All US authorities } & -0.040 & & -0.024 & & & & \\
\hline & $(0.082)$ & & $(0.081)$ & & & & \\
\hline \multirow[t]{2}{*}{ All Japanese authorities } & $0.118 *$ & & $0.166 * * *$ & & & & \\
\hline & $(0.062)$ & & $(0.059)$ & & & & \\
\hline \multirow[t]{2}{*}{ ECB President } & & $0.424 * * *$ & & 0.092 & $0.187 * * *$ & -0.096 & -0.043 \\
\hline & & $(0.097)$ & & $(0.126)$ & $(0.069)$ & $(0.080)$ & $(0.137)$ \\
\hline \multirow[t]{2}{*}{ US Treasury Secretary } & & -0.023 & & -0.029 & 0.063 & -0.028 & -0.043 \\
\hline & & $(0.087)$ & & $(0.082)$ & $(0.057)$ & $(0.055)$ & $(0.079)$ \\
\hline \multirow[t]{2}{*}{ Japanese Minister of Finance } & & $0.128 *$ & & $0.158 * *$ & -0.045 & 0.024 & 0.038 \\
\hline & & $(0.073)$ & & $(0.067)$ & $(0.046)$ & $(0.050)$ & (0.047) \\
\hline \multirow[t]{2}{*}{ Constant } & 0.014 & 0.019 & -0.002 & -0.002 & 0.008 & -0.005 & -0.009 \\
\hline & (0.014) & (0.014) & $(0.014)$ & (0.013) & (0.009) & (0.008) & $(0.012)$ \\
\hline Observations & 2,104 & 2,104 & 2,104 & 2,104 & 2,104 & 2,104 & 2,104 \\
\hline
\end{tabular}

Notes: Robust standard errors in parentheses.

(*) significant at $10 \% ;(* *)$ significant at $5 \% ;(* * *)$ significant at $1 \%$.

${ }^{1)}$ Nominal effective exchange rates

Table 2 reports regression results from the benchmark empirical model over January 2000-December 2007, namely:

$r_{t}=\alpha+\beta S_{t}+\sum_{k} \chi^{k} X_{t}^{k}+\varepsilon_{t}$

with $r_{t}$ as daily exchange rate returns, $S=S^{e}+S^{\text {res }}$ a $[-1 ; 0 ;+1]$ indicator variable capturing statements on both exchange rate regime and reserve composition and $X$ a vector of controls including statements by G3 authorities. The equation is estimated by OLS with robust standard errors. 
Table 3: Impact of official statements by emerging economy authorities on G3 exchange rates (Robustness checks; 1. Jan. 2000 - 31 Dec. 2007)

\begin{tabular}{|c|c|c|c|c|c|c|c|}
\hline & \multicolumn{4}{|c|}{ A. Bilateral exchange rates } & \multicolumn{3}{|c|}{ B. NEERs ${ }^{1)}$} \\
\hline & \multicolumn{2}{|c|}{ USD/EUR } & \multicolumn{2}{|c|}{ USD/JPY } & Euro & US dollar & Yen \\
\hline & (1) & (2) & (3) & (4) & (5) & (6) & (7) \\
\hline Emerging economy authorities & $0.233 * * *$ & & $0.127 * *$ & & $0.076 * * *$ & $-0.111 * * *$ & 0.056 \\
\hline & $(0.044)$ & & $(0.055)$ & $0.150 * *$ & $(0.029)$ & $(0.042)$ & $(0.050)$ \\
\hline - Alternative classification & & $\begin{array}{l}0.179 \text { *** } \\
(0.056)\end{array}$ & & $(0.057)$ & & & \\
\hline ECB President & $\begin{array}{l}0.424 \text { *** } \\
(0.100)\end{array}$ & & $\begin{array}{r}0.078 \\
(0.135)\end{array}$ & & $\begin{array}{l}0.210 * * * \\
(0.071)\end{array}$ & $\begin{array}{l}-0.142 * * \\
(0.072)\end{array}$ & $\begin{array}{l}-0.024 \\
(0.142)\end{array}$ \\
\hline - Alternative classification & & $\begin{array}{l}0.280 \text { *** } \\
(0.076)\end{array}$ & & $\begin{array}{r}0.051 \\
(0.083)\end{array}$ & & & \\
\hline US Treasury Secretary & $\begin{array}{r}-0.005 \\
(0.083)\end{array}$ & & $\begin{array}{l}-0.029 \\
(0.082)\end{array}$ & & $\begin{array}{r}0.066 \\
(0.060)\end{array}$ & $\begin{array}{l}-0.024 \\
(0.057)\end{array}$ & $\begin{array}{r}-0.062 \\
(0.081)\end{array}$ \\
\hline - Alternative classification & & $\begin{array}{r}-0.087 \\
(0.079)\end{array}$ & & $\begin{array}{r}-0.040 \\
(0.076)\end{array}$ & & & \\
\hline Japan's Minister of Finance & $\begin{array}{l}0.156 \text { ** } \\
(0.076)\end{array}$ & & $\begin{array}{l}0.162 * * \\
(0.068)\end{array}$ & & $\begin{array}{r}-0.045 \\
(0.047)\end{array}$ & $\begin{array}{r}0.023 \\
(0.051)\end{array}$ & $\begin{array}{r}0.020 \\
(0.046)\end{array}$ \\
\hline - Alternative classification & & $\begin{array}{l}0.159 \text { ** } \\
(0.068)\end{array}$ & & $\begin{array}{l}0.135 \text { ** } \\
(0.060)\end{array}$ & & & \\
\hline Actual Japanese interventions & & & $\begin{array}{l}0.0002 \text { ** } \\
(0.0001)\end{array}$ & $\begin{array}{l}0.0002 \text { ** } \\
(0.0001)\end{array}$ & & & $\begin{array}{c}0.0001 * \\
(0.0001)\end{array}$ \\
\hline US macroeconomic shocks & YES & & YES & & YES & YES & YES \\
\hline Constant & $\begin{array}{r}0.017 \\
(0.014)\end{array}$ & $\begin{array}{r}0.021 \\
(0.014)\end{array}$ & $\begin{array}{r}0.004 \\
(0.014)\end{array}$ & $\begin{array}{r}0.000 \\
(0.014)\end{array}$ & $\begin{array}{r}0.007 \\
(0.009)\end{array}$ & $\begin{array}{l}-0.007 \\
(0.008)\end{array}$ & $\begin{array}{r}0.000 \\
(0.012)\end{array}$ \\
\hline Observations & 2,083 & 2,104 & 2,083 & 2,104 & 2,083 & 2,083 & 2,083 \\
\hline
\end{tabular}

Notes: Robust standard errors in parentheses.

$(*)$ significant at $10 \% ;(* *)$ significant at $5 \% ;(* * *)$ significant at $1 \%$.

${ }^{1)}$ Nominal effective exchange rates

Table 3 reports robustness check results of the benchmark empirical model over January 2000-December 2007, namely:

$r_{t}=\alpha+\beta S_{t}+\sum_{k} \chi^{k} X_{t}^{k}+\varepsilon_{t}$

with $r_{t}$ as daily exchange rate returns, $S=S^{e}+S^{\text {res }}$ a $[-1 ; 0 ;+1]$ indicator variable capturing statements on both exchange rate regime and reserve composition and $X$ a vector of controls including, depending on the specification, statements by G3 authorities, US macroeconomic shocks and actual Japanese foreign exchange interventions. A further robustness check consists in testing an alternative classification, where all "neutral" statements (i.e. $S=0$ ) are classified into variables that go against the common policy mantra. For instance, a statement of a Japanese official which is neutral but comes in a period when the predominant policy stance is to weaken the yen - as e.g. occurred in most of 2002-04 - would code, under the alternative classification, as a deviation from the common policy mantra and thus as $S=+1$. The equation is estimated by OLS with robust standard errors. 
Table 4: Impact of official statements by emerging economy authorities on G3 exchange rates - Reserve composition vs. exchange rate regime; 1. Jan. 2000 - 31 Dec. 2007

\begin{tabular}{|c|c|c|c|c|c|c|c|c|c|c|}
\hline & \multicolumn{4}{|c|}{ A. Bilateral exchange rates } & \multicolumn{6}{|c|}{ B. NEERs ${ }^{1)}$} \\
\hline & \multicolumn{2}{|c|}{ USD/EUR } & \multicolumn{2}{|c|}{ USD/JPY } & \multicolumn{2}{|c|}{ Euro } & \multicolumn{2}{|c|}{ US dollar } & \multicolumn{2}{|c|}{ Yen } \\
\hline & (1) & (2) & (3) & (4) & (5) & (6) & (7) & (8) & (9) & (10) \\
\hline Emerging economy authorities & & & & & & & & & & \\
\hline - Reserve composition & $\begin{array}{l}0.243 * * * \\
(0.056)\end{array}$ & & $\begin{array}{c}0.149 * \\
(0.077)\end{array}$ & & $\begin{array}{l}0.079 \text { *** } \\
(0.030)\end{array}$ & & $\begin{array}{l}-0.095 * \\
(0.050)\end{array}$ & & $\begin{array}{l}-0.006 \\
(0.065)\end{array}$ & \\
\hline - Exchange rate regime & & $\begin{array}{l}0.234 \text { *** } \\
(0.057)\end{array}$ & & $\begin{array}{c}0.128 * \\
(0.077)\end{array}$ & & $\begin{array}{c}0.072 * \\
(0.040)\end{array}$ & & $\begin{array}{l}-0.107 * \\
(0.056)\end{array}$ & & $\begin{array}{r}0.078 \\
(0.070)\end{array}$ \\
\hline ECB President & $\begin{array}{l}0.427 \text { *** } \\
(0.096)\end{array}$ & $\begin{array}{l}0.415 \text { *** } \\
(0.095)\end{array}$ & $\begin{array}{r}0.094 \\
(0.123)\end{array}$ & $\begin{array}{r}0.087 \\
(0.124)\end{array}$ & $\begin{array}{l}0.188 * * * \\
(0.070)\end{array}$ & $\begin{array}{l}0.185 \text { *** } \\
(0.069)\end{array}$ & $\begin{array}{r}-0.097 \\
(0.082)\end{array}$ & $\begin{array}{c}-0.092 \\
(0.079)\end{array}$ & $\begin{array}{r}-0.044 \\
(0.136)\end{array}$ & $\begin{array}{r}-0.045 \\
(0.137)\end{array}$ \\
\hline US Treasury Secretary & $\begin{array}{l}-0.028 \\
(0.087)\end{array}$ & $\begin{array}{l}-0.027 \\
(0.087)\end{array}$ & $\begin{array}{l}-0.032 \\
(0.082)\end{array}$ & $\begin{array}{r}-0.032 \\
(0.082)\end{array}$ & $\begin{array}{r}0.061 \\
(0.057)\end{array}$ & $\begin{array}{r}0.061 \\
(0.057)\end{array}$ & $\begin{array}{l}-0.026 \\
(0.055)\end{array}$ & $\begin{array}{r}-0.026 \\
(0.055)\end{array}$ & $\begin{array}{r}-0.044 \\
(0.079)\end{array}$ & $\begin{array}{r}-0.044 \\
(0.079)\end{array}$ \\
\hline Japanese Minister of Finance & $\begin{array}{c}0.129 * \\
(0.073)\end{array}$ & $\begin{array}{c}0.132 \\
(0.073)\end{array}$ & $\begin{array}{l}0.159 \text { ** } \\
(0.067)\end{array}$ & $\begin{array}{l}0.161 \text { ** } \\
(0.067)\end{array}$ & $\begin{array}{r}-0.044 \\
(0.046)\end{array}$ & $\begin{array}{r}-0.044 \\
(0.046)\end{array}$ & $\begin{array}{r}0.023 \\
(0.050)\end{array}$ & $\begin{array}{r}0.022 \\
(0.050)\end{array}$ & $\begin{array}{r}0.039 \\
(0.047)\end{array}$ & $\begin{array}{r}0.038 \\
(0.047)\end{array}$ \\
\hline Constant & $\begin{array}{c}0.024 \\
(0.014)\end{array}$ & $\begin{array}{c}0.023 \\
(0.014)\end{array}$ & $\begin{array}{r}0.001 \\
(0.013)\end{array}$ & $\begin{array}{r}0.001 \\
(0.013)\end{array}$ & $\begin{array}{r}0.009 \\
(0.009)\end{array}$ & $\begin{array}{r}0.009 \\
(0.009)\end{array}$ & $\begin{array}{r}-0.008 \\
(0.008)\end{array}$ & $\begin{array}{r}-0.007 \\
(0.008)\end{array}$ & $\begin{array}{r}-0.007 \\
(0.012)\end{array}$ & $\begin{array}{r}-0.009 \\
(0.012)\end{array}$ \\
\hline Observations & 2,104 & 2,104 & 2,104 & 2,104 & 2,104 & 2,104 & 2,104 & 2,104 & 2,104 & 2,104 \\
\hline
\end{tabular}

Table 5: Impact of official statements by Chinese authorities on G3 exchange rates Reserve composition vs. exchange rate regime; 1. Jan. 2000 - 31 Dec. 2007

\begin{tabular}{|c|c|c|c|c|c|c|c|c|c|c|}
\hline & \multicolumn{4}{|c|}{ A. Bilateral exchange rates } & \multicolumn{6}{|c|}{ B. NEERs ${ }^{1)}$} \\
\hline & \multicolumn{2}{|c|}{ USD/EUR } & \multicolumn{2}{|c|}{ USD/JPY } & \multicolumn{2}{|c|}{ Euro } & \multicolumn{2}{|c|}{ US dollar } & \multicolumn{2}{|c|}{ Yen } \\
\hline & (1) & (2) & (3) & (4) & (5) & (6) & (7) & (8) & (9) & $(10)$ \\
\hline \multicolumn{11}{|l|}{ Chinese authorities } \\
\hline \multirow[t]{2}{*}{ - Reserve composition } & 0.048 & & -0.094 & & 0.093 & & -0.141 & & -0.143 & \\
\hline & $(0.104)$ & & $(0.212)$ & & $(0.057)$ & & $(0.103)$ & & $(0.176)$ & \\
\hline \multirow[t]{2}{*}{ - Exchange rate regime } & & $0.189 * * *$ & & $0.168 *$ & & 0.055 & & -0.080 & & 0.100 \\
\hline & & $(0.067)$ & & $(0.093)$ & & $(0.044)$ & & $(0.062)$ & & $(0.084)$ \\
\hline \multirow[t]{2}{*}{ ECB President } & $0.419 * * *$ & $0.426 * * *$ & 0.090 & 0.095 & $0.186 * * *$ & $0.188 * * *$ & -0.094 & -0.097 & -0.043 & -0.040 \\
\hline & $(0.094)$ & $(0.095)$ & $(0.122)$ & $(0.122)$ & $(0.070)$ & $(0.069)$ & $(0.008)$ & $(0.079)$ & $(0.136)$ & $(0.136)$ \\
\hline \multirow[t]{2}{*}{ US Treasury Secretary } & -0.029 & -0.028 & -0.031 & -0.032 & 0.060 & 0.061 & -0.023 & -0.026 & -0.042 & -0.044 \\
\hline & $(0.087)$ & $(0.087)$ & $(0.082)$ & $(0.082)$ & $(0.057)$ & $(0.057)$ & $(0.056)$ & $(0.055)$ & $(0.079)$ & $(0.079)$ \\
\hline \multirow[t]{2}{*}{ Japanese Minister of Finance } & $0.133 *$ & $0.135 *$ & $0.162 * *$ & $0.163 * *$ & -0.043 & -0.043 & 0.022 & 0.021 & 0.039 & 0.040 \\
\hline & $(0.073)$ & $(0.073)$ & $(0.067)$ & $(0.067)$ & $(0.046)$ & $(0.046)$ & $(0.050)$ & $(0.050)$ & $(0.047)$ & $(0.047)$ \\
\hline \multirow[t]{2}{*}{ Constant } & $0.028 *$ & $0.025 *$ & 0.004 & 0.000 & 0.010 & 0.009 & -0.009 & -0.008 & -0.006 & -0.009 \\
\hline & $(0.013)$ & $(0.014)$ & $(0.013)$ & $(0.013)$ & $(0.009)$ & $(0.009)$ & $(0.008)$ & $(0.008)$ & $(0.011)$ & $(0.012)$ \\
\hline Observations & 2,104 & 2,104 & 2,104 & 2,104 & 2,104 & 2,104 & 2,104 & 2,104 & 2,104 & 2,104 \\
\hline
\end{tabular}

Notes: Robust standard errors in parentheses.

$(*)$ significant at $10 \% ;(* *)$ significant at $5 \% ;(* *)$ significant at $1 \%$

${ }^{1)}$ Nominal effective exchange rates

Table 4 and 5 report robustness check results of the benchmark empirical model over January 2000-December 2007, namely:

$r_{t}=\alpha+\beta^{e} S_{t}^{e}+\beta^{r e s} S_{t}^{r e s} \sum_{k} \chi^{k} X_{t}^{k}+\varepsilon_{t}$

with $r_{t}$ as daily exchange rate returns, $S^{e}$ and $S^{\text {res }}$ as two $[-1 ; 0 ;+1]$ indicator variables capturing statements on exchange rate regime and reserve composition, respectively, and $X$ a vector of controls including statements by G3 authorities. The equation is estimated by OLS with robust standard errors. The equation is estimated by using statements by all emerging market policy-makers (Table 4) and only by Chinese policymakers (Table 5). 
Table 6: Impact of official statements by GCC authorities on G3 exchange rates Reserve composition vs. exchange rate regime; 1. Jan. 2005 - 31 Dec. 2007

\begin{tabular}{|c|c|c|c|c|c|c|c|c|c|c|}
\hline & \multicolumn{4}{|c|}{ A. Bilateral exchange rates } & \multicolumn{6}{|c|}{ B. NEERs ${ }^{1)}$} \\
\hline & \multicolumn{2}{|c|}{ USD/EUR } & \multicolumn{2}{|c|}{ USD/JPY } & \multicolumn{2}{|c|}{ Euro } & \multicolumn{2}{|c|}{ US dollar } & \multicolumn{2}{|c|}{ Yen } \\
\hline GCC authorities & (1) & (2) & (3) & (4) & (5) & (6) & (7) & (8) & (9) & $(10)$ \\
\hline - Reserve composition & $\begin{array}{l}0.362 \text { *** } \\
(0.104)\end{array}$ & & $\begin{array}{l}0.309 \text { ** } \\
(0.139)\end{array}$ & & $\begin{array}{c}0.126 \text { ** } \\
(0.053)\end{array}$ & & $\begin{array}{r}-0.141 \\
(0.099)\end{array}$ & & $\begin{array}{r}0.050 \\
(0.129)\end{array}$ & \\
\hline - Exchange rate regime & & $\begin{array}{l}0.479 \text { *** } \\
(0.088)\end{array}$ & & $\begin{array}{r}0.077 \\
(0.120)\end{array}$ & & $\begin{array}{l}0.296 * * * \\
(0.115)\end{array}$ & & $\begin{array}{r}-0.195 \\
(0.186)\end{array}$ & & $\begin{array}{l}-0.014 \\
(0.198)\end{array}$ \\
\hline ECB President & $\begin{array}{l}0.311 \text { *** } \\
(0.086)\end{array}$ & $\begin{array}{l}0.316^{* * *} \\
(0.086)\end{array}$ & $\begin{array}{r}0.056 \\
(0.213)\end{array}$ & $\begin{array}{r}0.062 \\
(0.213)\end{array}$ & $\begin{array}{c}0.130 * \\
(0.068)\end{array}$ & $\begin{array}{l}0.131 \\
(0.068)\end{array}$ & $\begin{array}{r}-0.078 \\
(0.109)\end{array}$ & $\begin{array}{r}-0.079 \\
(0.109)\end{array}$ & $\begin{array}{r}-0.073 \\
(0.239)\end{array}$ & $\begin{array}{l}-0.072 \\
(0.239)\end{array}$ \\
\hline US Treasury Secretary & $\begin{array}{l}-0.023 \\
(0.138)\end{array}$ & $\begin{array}{r}-0.028 \\
(0.138)\end{array}$ & $\begin{array}{r}0.062 \\
(0.124)\end{array}$ & $\begin{array}{r}0.055 \\
(0.124)\end{array}$ & $\begin{array}{l}-0.069 * \\
(0.038)\end{array}$ & $\begin{array}{l}-0.070 \text { * } \\
(0.038)\end{array}$ & $\begin{array}{r}0.024 \\
(0.112)\end{array}$ & $\begin{array}{r}0.026 \\
(0.112)\end{array}$ & $\begin{array}{r}0.141 \\
(0.149)\end{array}$ & $\begin{array}{r}0.140 \\
(0.149)\end{array}$ \\
\hline Japanese Minister of Finance & $\begin{array}{r}0.145 \\
(0.231)\end{array}$ & $\begin{array}{r}0.150 \\
(0.231)\end{array}$ & $\begin{array}{r}0.215 \\
(0.206)\end{array}$ & $\begin{array}{r}-0.208 \\
(0.206)\end{array}$ & $\begin{array}{c}-0.049 \\
(0.094)\end{array}$ & $\begin{array}{r}-0.048 \\
(0.094)\end{array}$ & $\begin{array}{r}-0.057 \\
(0.183)\end{array}$ & $\begin{array}{r}-0.059 \\
(0.183)\end{array}$ & $\begin{array}{r}-0.008 \\
(0.176)\end{array}$ & $\begin{array}{r}-0.007 \\
(0.176)\end{array}$ \\
\hline $\begin{array}{l}\text { Constant } \\
\text { Observations }\end{array}$ & $\begin{array}{r}0.008 \\
(0.017) \\
781\end{array}$ & $\begin{array}{r}0.014 \\
(0.017) \\
781\end{array}$ & $\begin{array}{r}-0.022 \\
(0.020) \\
781\end{array}$ & $\begin{array}{r}-0.015 \\
(0.020) \\
781\end{array}$ & $\begin{array}{r}0.008 \\
(0.009) \\
781\end{array}$ & $\begin{array}{r}0.009 \\
(0.009) \\
781\end{array}$ & $\begin{array}{r}-0.007 \\
(0.013) \\
781\end{array}$ & $\begin{array}{r}-0.009 \\
(0.013) \\
781\end{array}$ & $\begin{array}{r}-0.021 \\
(0.017) \\
781\end{array}$ & $\begin{array}{r}-0.020 \\
(0.017) \\
781\end{array}$ \\
\hline
\end{tabular}

$(*)$ significant at $10 \% ;(* *)$ significant at $5 \% ;(* * *)$ significant at $1 \%$.

${ }^{1)}$ Nominal effective exchange rates

Table 6: Impact of official statements by Russian authorities on G3 exchange rates Reserve composition vs. exchange rate regime; 1. Jan. 2004 - 31 Dec. 2007

\begin{tabular}{|c|c|c|c|c|c|c|c|c|c|c|}
\hline & \multicolumn{4}{|c|}{ A. Bilateral exchange rates } & \multicolumn{6}{|c|}{ B. NEERs ${ }^{1)}$} \\
\hline & \multicolumn{2}{|c|}{ USD/EUR } & \multicolumn{2}{|c|}{ USD/JPY } & \multicolumn{2}{|c|}{ Euro } & \multicolumn{2}{|c|}{ US dollar } & \multicolumn{2}{|c|}{ Yen } \\
\hline Russian authorities & (1) & (2) & (3) & (4) & (5) & (6) & (7) & (8) & (9) & (10) \\
\hline - Reserve composition & $\begin{array}{l}0.260 \text { ** } \\
(0.108)\end{array}$ & & $\begin{array}{r}0.195 \\
(0.132)\end{array}$ & & $\begin{array}{r}-0.037 \\
(0.073)\end{array}$ & & $\begin{array}{r}0.001 \\
(0.095)\end{array}$ & & & \\
\hline - Exchange rate regime & & $\begin{array}{l}0.413 \text { *** } \\
(0.149)\end{array}$ & & $\begin{array}{l}-0.106 \\
(0.147)\end{array}$ & & $\begin{array}{r}0.120 \\
(0.094)\end{array}$ & & $\begin{array}{l}-0.400 * * * \\
(0.098)\end{array}$ & $\begin{array}{r}0.039 \\
(0.103)\end{array}$ & $\begin{array}{r}0.039 \\
(0.103)\end{array}$ \\
\hline ECB President & $\begin{array}{l}0.281 \text { *** } \\
(0.089)\end{array}$ & $\begin{array}{l}0.236 \text { *** } \\
(0.082)\end{array}$ & $\begin{array}{r}0.076 \\
(0.171)\end{array}$ & $\begin{array}{r}0.071 \\
(0.166)\end{array}$ & $\begin{array}{r}0.066 \\
(0.067)\end{array}$ & $\begin{array}{r}0.060 \\
(0.067)\end{array}$ & $\begin{array}{r}0.003 \\
(0.098)\end{array}$ & $\begin{array}{r}0.031 \\
(0.100)\end{array}$ & $\begin{array}{l}-0.057 \\
(0.192)\end{array}$ & $\begin{array}{r}-0.057 \\
(0.192)\end{array}$ \\
\hline US Treasury Secretary & $\begin{array}{l}-0.087 \\
(0.139)\end{array}$ & $\begin{array}{l}-0.091 \\
(0.139)\end{array}$ & $\begin{array}{l}-0.080 \\
(0.120)\end{array}$ & $\begin{array}{l}-0.082 \\
(0.120)\end{array}$ & $\begin{array}{r}-0.053 \\
(0.055)\end{array}$ & $\begin{array}{l}-0.053 \\
(0.055)\end{array}$ & $\begin{array}{r}0.064 \\
(0.092)\end{array}$ & $\begin{array}{r}0.066 \\
(0.092)\end{array}$ & $\begin{array}{r}0.064 \\
(0.122)\end{array}$ & $\begin{array}{r}0.064 \\
(0.122)\end{array}$ \\
\hline Japanese Minister of Finan & $\begin{array}{l}0.221 \\
(0.114)\end{array}$ & $\begin{array}{l}0.222 \\
(0.113)\end{array}$ & $\begin{array}{r}0.124 \\
(0.102)\end{array}$ & $\begin{array}{r}0.125 \\
(0.102)\end{array}$ & $\begin{array}{r}0.041 \\
(0.045)\end{array}$ & $\begin{array}{r}0.04 \\
(0.045)\end{array}$ & $\begin{array}{r}-0.062 \\
(0.074)\end{array}$ & $\begin{array}{l}-0.062 \\
(0.074)\end{array}$ & $\begin{array}{l}-0.004 \\
(0.064)\end{array}$ & $\begin{array}{r}-0.004 \\
(0.064)\end{array}$ \\
\hline Constant & $\begin{array}{c}0.029 * \\
(0.017)\end{array}$ & $\begin{array}{c}0.029 * \\
(0.017)\end{array}$ & $\begin{array}{r}0.001 \\
(0.018)\end{array}$ & $\begin{array}{r}0.002 \\
(0.018)\end{array}$ & $\begin{array}{r}0.012 \\
(0.009)\end{array}$ & $\begin{array}{r}0.012 \\
(0.009)\end{array}$ & $\begin{array}{r}-0.016 \\
(0.012)\end{array}$ & $\begin{array}{r}-0.015 \\
(0.012)\end{array}$ & $\begin{array}{r}-0.015 \\
(0.015)\end{array}$ & $\begin{array}{r}-0.015 \\
(0.015)\end{array}$ \\
\hline Observations & 1,043 & 1,043 & 1,043 & 1,043 & 1,043 & 1,043 & 1,043 & 1,043 & 1,043 & 1,043 \\
\hline
\end{tabular}

otes: Robust standard errors in parentheses

(*) significant at $10 \% ;(* *)$ significant at $5 \% ;(* * *)$ significant at $1 \%$.

${ }^{1)}$ Nominal effective exchange rates

Table 6 and 7 report robustness check results of the benchmark empirical model over January 2000-December 2007, namely:

$r_{t}=\alpha+\beta^{e} S_{t}^{e}+\beta^{r e s} S_{t}^{r e s} \sum_{k} \chi^{k} X_{t}^{k}+\varepsilon_{t}$

with $r_{t}$ as daily exchange rate returns, $S^{e}$ and $S^{\text {res }}$ as two $[-1 ; 0 ;+1]$ indicator variables capturing statements on exchange rate regime and reserve composition, respectively, and $X$ a vector of controls including statements by G3 authorities. The equation is estimated by OLS with robust standard errors. The equation is estimated by using statements only by GCC policy-makers (Table 6) and Russian policy-makers (Table 7). 
Table 8: Impact of official statements by EME authorities on exchange rate volatility EGARCH estimation results; 1. Jan. 2000 - 31 Dec. 2007

\begin{tabular}{|c|c|c|c|c|c|c|c|c|c|c|}
\hline & \multicolumn{7}{|c|}{ A. Bilateral exchange rates } & \multicolumn{3}{|c|}{ B. NEERs ${ }^{1)}$} \\
\hline & \multicolumn{4}{|c|}{ USD/EUR } & \multicolumn{3}{|c|}{ USD/JPY } & Euro & US dollar & Yen \\
\hline & (1) & (2) & (3) & (4) & (5) & (6) & (7) & (8) & (9) & (10) \\
\hline \multicolumn{11}{|l|}{ Mean equation } \\
\hline \multirow[t]{2}{*}{ Emerging economy authorities } & $0.231 * * *$ & $0.228 * * *$ & $0.224 * * *$ & $0.227 * * *$ & $0.149 * * *$ & $0.151 * * *$ & $0.156 * * *$ & $0.062 * *$ & $-0.108 * * *$ & 0.024 \\
\hline & $(0.051)$ & $(0.051)$ & $(0.050)$ & & $(0.050)$ & $(0.051)$ & $(0.051)$ & $(0.025)$ & $(0.025)$ & $(0.038)$ \\
\hline \multirow[t]{2}{*}{ ECB President } & $(0.394) * * *$ & & & $0.392 * * *$ & & & 0.169 & $0.155 * *$ & -0.083 & -0.052 \\
\hline & $(0.150)$ & & & $(0.141)$ & & & $(0.120)$ & $(0.068)$ & $(0.078)$ & $(0.133)$ \\
\hline \multirow[t]{2}{*}{ US Treasury Secretary } & & -0.064 & & -0.042 & -0.009 & & 0.007 & -0.003 & -0.036 & -0.002 \\
\hline & & $(0.071)$ & & $(0.073)$ & $(0.073)$ & & $(0.074)$ & $(0.043)$ & $(0.055)$ & $(0.050)$ \\
\hline \multirow[t]{2}{*}{ Japan's Finance Minister } & & & 0.100 & 0.102 & & $0.131 *$ & $0.132 *$ & -0.036 & 0.041 & 0.01 \\
\hline & & & $(0.074)$ & $(0.075)$ & & $(0.074)$ & $(0.074)$ & $(0.039)$ & $(0.048)$ & $(0.049)$ \\
\hline \multirow[t]{2}{*}{ Constant } & $0.019 *$ & 0.016 & -0.018 & $0.023 *$ & -0.007 & -0.002 & -0.001 & $0.012 *$ & -0.004 & -0.008 \\
\hline & $(0.012)$ & $(0.012)$ & $(0.012)$ & $(0.012)$ & $(0.013)$ & $(0.013)$ & $(0.013)$ & $(0.007)$ & $(0.082)$ & $(0.011)$ \\
\hline \multicolumn{11}{|l|}{ Conditional variance equation } \\
\hline Emerging economy authorities & $-0.037 * *$ & $-0.026 *$ & $-0.049 * *$ & $0.040 * *$ & $-0.087 * * *$ & $-0.088 * * *$ & $-0.084 * * *$ & $-0.049 *$ & $0.357 * * *$ & $-0.093 * * *$ \\
\hline ECB President & $(0.043)$ & & & $(0.050)$ & & & $(0.090)$ & $(0.056)$ & $(0.306)$ & $(0.091)$ \\
\hline \multirow[t]{2}{*}{ US Treasury Secretary } & & $0.046 *$ & & $0.046 *$ & 0.015 & & 0.000 & 0.006 & $0.391 * *$ & 0.021 \\
\hline & & $(0.025)$ & & $(0.025)$ & $(0.050)$ & & $(0.050)$ & $(0.037)$ & $(0.174)$ & $(0.043)$ \\
\hline \multirow[t]{2}{*}{ Japan's Finance Minister } & & & $-0.034 *$ & $-0.041 * * *$ & & -0.038 & $-0.042 *$ & -0.016 & $-0.401 * *$ & 0.027 \\
\hline & & & $(0.013)$ & $(0.016)$ & & $(0.026)$ & $(0.027)$ & $(0.018)$ & $(0.172)$ & $(0.027)$ \\
\hline \multirow[t]{2}{*}{ Constant } & -0.001 & $-0.004 * *$ & $-0.004 * *$ & $-0.008 * * *$ & $-0.040 * * *$ & $-0.041 * * *$ & $-0.040 * * *$ & -0.009 & $-1.811 * * *$ & $-0.027 * * *$ \\
\hline & $(0.001)$ & $(0.002)$ & $(0.002)$ & $(0.002)$ & $(0.011)$ & $(0.011)$ & $(0.011)$ & $(0.004)$ & $(0.357)$ & $(0.007)$ \\
\hline
\end{tabular}

Notes: Robust standard errors in parentheses.

$(*)$ significant at $10 \% ;(* *)$ significant at $5 \% ;(* *)$ significant at $1 \%$.

${ }^{1)}$ Nominal effective exchange rates

Table 8 reports regression results over January 2000-December 2007 of an alternative specification to the benchmark empirical model where daily exchange rate returns are modelled as an exponential GARCH (EGARCH) à la Nelson (1991) in order to account for non-normality, negative skewness, excess kurtosis and serial correlation in the data (see e.g. Fratzscher, 2008c for further details). The conditional variance of the daily exchange rates is expressed as a function of past variance, innovations and oral statements. 
Table 9 - Explanatory power of official statements of daily exchange rate movements

\begin{tabular}{|c|c|c|c|c|c|c|c|c|c|c|}
\hline \multirow[b]{3}{*}{ A. USD/EUR exchange rate } & \multicolumn{10}{|c|}{ Author(s) of official statements included as explanatory variable(s) in the regression } \\
\hline & \multicolumn{2}{|c|}{ ECB President } & \multicolumn{2}{|c|}{$\begin{array}{c}\text { Emerging market } \\
\text { authorities }\end{array}$} & \multicolumn{2}{|c|}{ US Treasury Secretary } & \multicolumn{2}{|c|}{$\begin{array}{c}\text { Japan's Minister of } \\
\text { Finance }\end{array}$} & \multicolumn{2}{|c|}{ All combined } \\
\hline & $R^{2}$ & (obs.) & $R^{2}$ & (obs.) & $R^{2}$ & (obs.) & $R^{2}$ & (obs.) & $R^{2}$ & (obs.) \\
\hline - On any given day & 0.004 & $(2,104)$ & 0.008 & $(2,104)$ & 0.000 & $(2,104)$ & 0.000 & $(2,104)$ & 0.014 & $(2,104)$ \\
\hline - On statement days & 0.329 & (63) & 0.145 & $(295)$ & 0.063 & (82) & 0.060 & (166) & 0.063 & (671) \\
\hline \multicolumn{11}{|l|}{ B. USD/JPY exchange rate } \\
\hline - On any given day & 0.000 & $(2,104)$ & 0.002 & $(2,104)$ & 0.000 & $(2,104)$ & 0.002 & $(2,104)$ & 0.005 & $(2,104)$ \\
\hline - On statement days & 0.018 & (63) & 0.042 & $(295)$ & 0.029 & (82) & 0.067 & (166) & 0.037 & (671) \\
\hline \multicolumn{11}{|l|}{ C. Euro } \\
\hline - On any given day & 0.002 & $(2,104)$ & 0.001 & $(2,158)$ & 0.000 & $(2,104)$ & 0.000 & $(2,104)$ & 0.004 & $(2,104)$ \\
\hline - On statement days & 0.179 & (63) & 0.042 & $(295)$ & 0.000 & (82) & 0.006 & (166) & 0.035 & (671) \\
\hline \multicolumn{11}{|l|}{ D. US dollar } \\
\hline - On any given day & 0.000 & $(2,104)$ & 0.003 & $(2,158)$ & 0.000 & $(2,104)$ & 0.000 & $(2,104)$ & 0.005 & $(2,104)$ \\
\hline - On statement days & 0.059 & (63) & 0.055 & $(295)$ & 0.011 & (82) & 0.002 & (166) & 0.018 & (671) \\
\hline \multicolumn{11}{|l|}{ D. Yen } \\
\hline - On any given day & 0.000 & $(2,104)$ & 0.000 & $(2,158)$ & 0.000 & $(2,104)$ & 0.000 & $(2,104)$ & 0.001 & $(2,104)$ \\
\hline - On statement days & 0.002 & (63) & 0.002 & $(295)$ & 0.014 & (82) & 0.013 & (166) & 0.008 & $(671)$ \\
\hline
\end{tabular}

Table 9 reports measures of overall goodness-of-fit of the benchmark empirical model in which the models are estimated only for those days when policy-makers in individual economies issued statements, as compared to all days. 


\section{Table 10: Impact of official statements on the USD/EUR under selected market conditions}

(1. Jan. 2000 - 31 Dec. 2007)

\begin{tabular}{|c|c|c|c|c|c|c|}
\hline & (1) & (2) & (3) & (4) & (5) & $(6)$ \\
\hline \multicolumn{7}{|l|}{ "Low" volatility ${ }^{1)}$} \\
\hline - ECB President & $\begin{array}{l}0.346 * * * \\
(0.076)\end{array}$ & $\begin{array}{l}0.355 * * * \\
(0.083)\end{array}$ & & & & \\
\hline - Emerging economy authorities & & $\begin{array}{l}0.235 * * * \\
(0.045)\end{array}$ & & & & \\
\hline \multicolumn{7}{|l|}{ "High" volatility ${ }^{1)}$} \\
\hline - ECB President & $\begin{array}{l}0.535 * * * \\
(0.198)\end{array}$ & $\begin{array}{l}0.530 * * * \\
(0.199)\end{array}$ & & & & \\
\hline - Emerging economy authorities & & $\begin{array}{l}0.274 * * \\
(0.128)\end{array}$ & & & & \\
\hline \multicolumn{7}{|c|}{ Absence of exchange rate "misalignment" } \\
\hline - Euro area authorities & & & $\begin{array}{r}0.043 \\
(0.111)\end{array}$ & $\begin{array}{r}0.052 \\
(0.111)\end{array}$ & & \\
\hline \multicolumn{2}{|l|}{ - Emerging economy authorities } & & & $\begin{array}{l}0.163 * * * \\
(0.053)\end{array}$ & & \\
\hline \multicolumn{7}{|l|}{ Exchange rate "misalignment" ${ }^{2)}$} \\
\hline - Euro area authorities & & & $\begin{array}{l}0.246 \text { *** } \\
(0.069)\end{array}$ & $\begin{array}{l}0.257 * * * \\
(0.069)\end{array}$ & & \\
\hline \multicolumn{2}{|l|}{ - Emerging economy authorities } & & & $\begin{array}{l}0.311 * * * \\
(0.062)\end{array}$ & & \\
\hline \multicolumn{7}{|l|}{ "Leaning against the wind" ${ }^{3)}$} \\
\hline - ECB President & & & & & $\begin{array}{l}0.602 \text { *** } \\
(0.196)\end{array}$ & $\begin{array}{l}0.602 \text { *** } \\
(0.200)\end{array}$ \\
\hline - Emerging economy authorities & & & & & & $\begin{array}{r}0.002 \\
(0.108)\end{array}$ \\
\hline Constant & $\begin{array}{c}0.023 * \\
(0.013)\end{array}$ & $\begin{array}{r}0.014 \\
(0.013)\end{array}$ & $\begin{array}{r}0.02 \\
(0.013)\end{array}$ & $\begin{array}{r}0.011 \\
(0.013)\end{array}$ & $\begin{array}{r}0.215 \\
(0.168)\end{array}$ & $\begin{array}{r}0.215 \\
(0.170)\end{array}$ \\
\hline Observations & 2,104 & 2,104 & 2,104 & 2,104 & 35 & 35 \\
\hline \multicolumn{6}{|c|}{ Notes: Robust standard errors in parentheses. } & $(*)$ significant at $10 \% ;(* *)$ significant at $5 \% ;(* * *)$ significant at $1 \%$ \\
\hline \multicolumn{7}{|c|}{${ }^{1)}$ Periods of low (high) volatility are defined as those when the 1-month historical volatility of the daily USD/EUR return is below (above) average. } \\
\hline \multicolumn{7}{|c|}{${ }^{3)}$ A statement "leans against the wind" if it goes in the direction opposite to exchange rate trend (defined here as the 3-month change in the USD/EUR). } \\
\hline
\end{tabular}


Table 11: Evidence for the expectations channel

(1. Jan. 2000 - 31 Dec. 2007)

\begin{tabular}{|c|c|c|c|c|c|}
\hline \multirow[b]{2}{*}{ Emerging economy authorities } & \multicolumn{5}{|c|}{ USD/EUR } \\
\hline & $\begin{array}{l}0.228 \text { ** } \\
(0.101)\end{array}$ & $\begin{array}{l}0.377 * * * \\
(0.051)\end{array}$ & $\begin{array}{l}0.405 * * * \\
(0.054)\end{array}$ & $\begin{array}{l}0.392 * * * \\
(0.054)\end{array}$ & $\begin{array}{l}0.366 \text { *** } \\
(0.052)\end{array}$ \\
\hline Emerging economy authorities $x$ & $0.590 *$ & & & & \\
\hline Lagged renminbi expected appreciation ${ }^{1}$ & $(0.361)$ & & & & \\
\hline Emerging economy authorities $x$ & & 0.355 & & & \\
\hline Lagged Saudi riyal expected appreciation $^{1}$ & & $(0.321)$ & & & \\
\hline Emerging economy authorities $x$ & & & $0.417 *$ & & \\
\hline Lagged Kuwaiti dinar expected appreciation ${ }^{1}$ & & & $(0.230)$ & & \\
\hline Emerging economy authorities $x$ & & & & & 0.292 \\
\hline Lagged UAE dirham expected appreciation $^{1}$ & & & & & $(0.255)$ \\
\hline Emerging economy authorities $x$ & & & & 0.091 & \\
\hline Lagged Barhaini dinar expected appreciation ${ }^{1}$ & & & & $(0.210)$ & \\
\hline All euro area authorities & $\begin{array}{r}0.142 \\
(0.121)\end{array}$ & $\begin{array}{r}0.140 \\
(0.119)\end{array}$ & $\begin{array}{r}0.113 \\
(0.116)\end{array}$ & $\begin{array}{r}0.165 \\
(0.116)\end{array}$ & $\begin{array}{r}0.134 \\
(0.118)\end{array}$ \\
\hline Lagged emerging currency expected appreciation & $\begin{array}{r}-0.014 \\
(0.016)\end{array}$ & $\begin{array}{r}-0.015 \\
(0.017)\end{array}$ & $\begin{array}{r}-0.016 \\
(0.016)\end{array}$ & $\begin{array}{r}0.007 \\
(0.016)\end{array}$ & $\begin{array}{r}-0.015 \\
(0.017)\end{array}$ \\
\hline Constant & $\begin{array}{l}-0.322 \text { ** } \\
(0.154)\end{array}$ & $\begin{array}{l}-0.187 * \\
(0.107)\end{array}$ & $\begin{array}{l}-0.314 * * \\
(0.136)\end{array}$ & $\begin{array}{l}-0.190 * * * \\
(0.073)\end{array}$ & $\begin{array}{r}-0.114 \\
(0.070)\end{array}$ \\
\hline Observations $^{2)}$ & 254 & 254 & 254 & 230 & 254 \\
\hline$R^{2}$ & 0.15 & 0.14 & 0.15 & 0.18 & 0.14 \\
\hline
\end{tabular}

Notes: Robust standard errors in parentheses.

(*) significant at $10 \%$; (**) significant at 5\%; (***) significant at $1 \%$.

1) 1-year forward rate minus spot exchange rate vs. US dollar. The variable is normalised to lie between 0 and 1 .

${ }^{2)}$ The estimation is done only on days when there are statements by emerging economy authorities.

Table 11 reports robustness check results using a modified version of the benchmark model over January 2000-December 2007, namely: $r_{t}=\alpha+\beta_{1} S_{t}+\beta_{2}\left[S_{t} \times\left(f_{t-1}^{1 y}-e_{t-1}\right)\right]+\varepsilon_{t}$

with $r_{t}$ as daily exchange rate returns, $S=S^{e}+S^{\text {res }}$ a $[-1 ; 0 ;+1]$ indicator variable capturing statements on both exchange rate regime and reserve composition, $(f-e)$ the (lagged) difference between the 1-year non-deliverable forward rate and the spot rate of a given emerging market currency which is used to proxy market expectations of an impending change in the corresponding country's currency regime. The equation is estimated by OLS with robust standard errors. 